\title{
파 파 0 파
}

\section{THE SPECIAL COMMITTEE}

APPOINTED EY THE HOUSE OF EEPRESENTATIVES, OF THE SEVENTH GENERAL ASSEMBLY, TO INVESTIGATE ALLEGED FRAUDS IN THE LOCATION OF THE CAPTTOL.

DES MOINES, IOWA :

J. TEKSDALK, STATE PRINTER, CITIZEN OFFICE, ::::::::::
1858. 


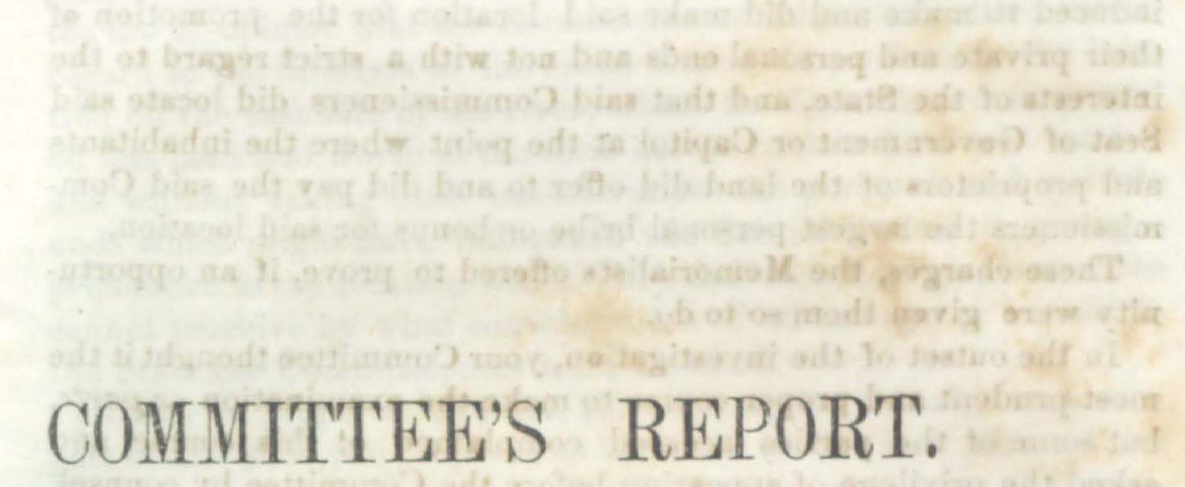

The Special Committee, appointed by the House of Representatipis to investigate the alleged frauds in the location of the Capitol of the State of Iowa, and to whom was referred the Memorial of citizens of Polk County alleging that the Commissioners appointed to locate the Seat of Government did not act for the best interests of the State, but that they did act fraudulently and corraptly in making such location, have had the whole matter under consideration and beg leave to

\section{R E P O R T ;}

The charges contained in the Memorial appeared to the Committee not to be sufficiently explicit or specific, they therefore notified the Memorialists through W. C. Burton, one of their number, that to warrant an investigation more specific charges should be preferred. Accordingly certain of tbe Memorialists, whose signatures are thereto subscribed, preferred the charges accompanying this Report, marked F, for the convenience of reference.

The substance of these charges, it will be seen, is

First - That the said Commissioners, viz: J. H. D. Street, Stewart Goodrell, Benjamin R. Pegram, Guy Wells and John A L. Crookham, in making the location on the East side of the Des Moines River, did not act with a "strict regard to the interests of the entire State," and

Second-That they or a majority of them, suffered themselves to be and were improperly influenced in their decision, and were 
induced to make and did make said location for the promotion of their private and personal ends and not with a strict regard to the interests of the State, and that said Commissieners did locate said Seat of Government or Capitol at the point where the inhabitants and proprietors of the land did offer to and did pay the said Commissioners the largest personal bribe or bonus for said location.

These eharges, the Memorialists offered to prove, if an opportunity were given them so to do.

In the outset of the investigation, your Committee thought it the most prudent and proper course to make the examination ex parte, but some of the parties aceased complained of this course, and asked the privilege of appearing before the Committee by connsel, which was granted; thenceforth the investigation assumed a more formal course as will be seen by the testimony appended to this Report.

To sustain the first charge the Memorialists introduced the testimony of F. C. Grimmel, Lovell White, W. C. Burton and others.

From the testimony of Mr. Grimmel, it appears that twenty acres of land was offered to the Commissioners for the State to be used as the location of the Capitol-this land appears from the testimony to have been worth nearly one hundred thousand dollars. It appears from the testimony of Lovell White, W. C. Burton, F. R. West and others, that besides this twenty acres of land, various persons, proprietors of lands (and otherwise interested on the west side of the river, offered, or gave the Commissioners notice that they would offer, $\$ 200,000$ worth of real estate at a fair price, as a further indncement or bonus to the State, for the location of the Capitol on the west side of the Des Moines River, or in Des Moines City proper. When the Commissioners received the notice that the subscription for the $\$ 200,000$ worth of real estate would be made and offered to them for the benefit of the State, they signified their willingness to give the proposition due consideration, and delay their final decision till the next day: but it appears that instead of so delaying, or giving the parties interested in the raising of the $\$ 200,000$ aforesaid an opportunity to present their proposition, they came to a decision which debarred those interested parties from making their proposition in time for its having any effect.

Compared with the advantages and benefits both in the location itself and in the comparative value of the land offered by Grim- mell and others on the west side of the Des Moines, your Committee are ot opinion that the Commissioners did not act with a "strict regard to the interests of the entire State," in preferring the location on the east side of the river, where the Commissioners receiv: ed less land and worth at the time not more than $\$ 150$ per acreand withont taking into consideration the personal and private ends which might have influenced the Commissioners in giving a make, your Committee preferentions of advantage or benefit to the State the Commissioners were actnated.

It may be proper to add that the subseription actually made as a (o the seen also from the testiriver, amounted to $\$ 159,350$. It will be seciptions mony that the accused attempted the Commissioners could have were not made in good faith, but as the Com a condition precerequired the payment of these subseripthe Capitol, your Commitdent or contingent upon the location of the Capitol, Your Committee tee set no value upon that part of the testion Commissioners are therefore of the opinion that each and all of the entire State, did not act with a strict regard to the inter

and that the first charge is substantiated.

To prove the second charge, the Memorianists introm others, Messrs. Baldwin, Scott, Williamson and Mitchell, npon whose testimony they relied to show that a large amount of property, estimated to be worth about fifty thousand dollars, was given to the Commissioners as a bribe, bonus or gratuity to influence them the witnesses, as the Committee have in making the location. House of Representatives, refused to testify already reported to the House have not on important points of the investigation, should not give true and yet determined whether they shonld or should committee. This proper answers to the interrogatories of the Committee. This contumacy of the principal witnesses, as your Com evidence, which liged to consider it, leaves the Committee without But even withmay, if elicited, settle the whole question at issue. your Committee out this, sufficient has been elicited to coners, was influenced, as that $\mathrm{Mr}$. Pegram, one of the Commissioners, was consideracharged, in making the location by personal a receive a bribe or bonus in tions and that he, the said Pegram, did receive a britol. That these consideration of his vote for the location of the are of opinion by the

conclusions are warranted, your Committee are of 
It appears from the testimony of $\mathrm{Mr}$. $\mathrm{V}$ an, that two hundred and fifty lots were set apart by proprietors of land and town lots on the east side of the river to influence the location of the Capitol, and it appears from the testimony of both Mr. Lyon, who gave some property, and of $\mathrm{Mr}$. Baldwin who received it for his influence with the Commissioners, as it was understood, that town lots or interests in town lots were given to effect the location. It has already been stated as the opinion of the Committee that Mr. Pegram was brib. ed, and if anything was wanting to confirm this belief, it is furnished both in the testimony of $\mathrm{Mr}$. Baldwin and of others who prove the close intimacy which existed between Baldwin and Pegram pending the sessions of the Commissioners. Indeed it appears conclusive that Baldwin was the agent or go-between Pegram, if not more of the Commissioners, and the proprietors of lands and others interested in town property on both sides of the river. He, Baldwin, appeared to have Pegram, if not a majority of the Commissioners for sale to the highest bidder, whether by the knowledge or consent of the Commissioners, except Pegram, is left to presumption.

Mr. J. B. Stewart testifies that Guy Wells, one of the Commissioners, was interested to the extent of ten acres at the time, and before the Capitol was located, in lands near the said location, which, of course, would be largely appreciated in value by the location. It appears further that this purchase was made at or about the time the act was passed for re-locating the Capitol or Seat of Government. Your Committee content themselves with stating this fact although they might be warranted in drawing an inference unfavorable to the Commissioners from the circumstance of his being interested as before stated.

Although there is no positive testimony connecting $\mathrm{Mr}$. Street and Mr. Crookham with any of the two hundred and fifty lots which were said to be placed at some persons disposition for the use and benefit of the Commissioners, yet the circumstantial testimony of several of the witnesses goes far, if not to a necessary extent, to connect them in interest with some of that property, and that they became so interested in consideration of their having voted to locate the Seat of Government where it now is. The testimony by which it was expected, and by which only it could be proved that they and it was alleged, that all of the Commissioners except Pegram, could be positively identified with fraud and cor- ruption, was withheld and it was not in the power of the Commitjustice to themselves the Committee will tee to bring it out. In justice to themselves the Committee made a state here what is already known to the House, that the refused to special report of the fact that several of the witnesses refused to testify, or more properly speaking, that they refused to answ to this terrogatories put to them, and that the House have not witnesses. time directed what disposition should be made of these witnese ap-

With regard to the fifth Commissioner, Mr. Goodrell, the him in pears to be nothing in the testimony elicited implicating that he the frauds alleged in the second charge. It does appeation was purchased property near the Capitol site after the made, as of course he had a right to do.

this investigation and report to a close, your ComIn bringing this investigation and report to a che hes the have been placed was disagreeable in the extreme. eited parties whose passions were aroused, it was exther in every cult to avoid incurring the displeasure of one or the th both parties step of the investigation, but we trust that our all the impartiality and to the State has been discharged with an investigation. which disinterested umpires could bring to such an investig

Of this, however, let the proper tribunal be the jug ittee may not

Finally, in order that the conclusions of the Committee way affect mislead or prejudice the judgment of others or hereby append the other persons opinions than their own, they hert.

testimony taken by the Committee to this Report.

All of which is respectfully submitted, E. G. COLLINS,
H. ANTHONY,

B. MILLISER,

\section{A. MAHONY.}

a member of the aforesaid Committee, desire the majority of the Committee.

The undersigned does not give his opinion as to whether the loation of the Capitol, made by the Commissioners, was the best that could have been made or not, believing as he does that the Committee is not called upon to express an opinion upon that point. He conceives the question to be decided by the Committee to be whether the Commissioners knowingly and intentionally disregardest interests of the whole State. The question as to where 
the location should, under all the circumstances, have been made, is one about which men may honestly differ, being simply a matter of opinion. He does not desire that the Commissioners shouid suffer on account of having acted contrary to what he might conceive to be for the best interests of the State. He would not have them judged by his mere opinion, nor does he believe that they ought to be judged by the opinion of the Committee, unless the Committee believe from the evidence that they have wilfully disregarded the interests of the whole State. As one of the Committee, bound to believe that the Commissioners acted in accordance with their oaths, until the contrary is proved, the undersigned feels bound to say that, with the exception of Commissioner Pegram, he ean see no sufficient evidence of a wiltul disregard of the interests of the State.

The undersigned believes from the evidence that at least a very considerable part of the subscription which was raised on the west side of the river, was not bona fide, and that a number of those who signed the same did so without expecting ever to be called upon to pay the same. The undersigned does not believe that the amount of said subscription, which it is reasonable to presume would have been paid in real estate at the then inflated prices, ought to have been sufficient to induce the Commissioners to loeate the Capitol at any place where, in their opinion, it ought not to have been located with a view to the future of the State. The undersigned deems it proper to say that there is some testimony, tending strongly to show that the subscription was not presented to the Commissioners, until after they had agreed upon a location.

The undersigned is not willing to presume that the answers of witnesses who refused to testify, would implicate persons who are not implicated by the other testimony. He thinks such a presumption both dangerous and unwarranted. When the answors are elicited he will give them all the force they deserve.

The undersigned thinks there is no force in the fact that Guy Wells owned a small tract of land near where the location was made, inasmuch as he purchased it long before the location was made and before the law was passed under which he was appointed a Commissioner. The undersigned believes that the charges are sustained by the evidence as to Commissioner Pegram, but not as to the other Commissioners.

[Signed,] GEO. W. MoCRARY, of said Committee.

\section{SUPPLEMENTAL REPORT.}

The Special Committee, appointed to investigate the alleged frauds in the location of the Seat of Government, recommend that Section $\mathbf{2 6 4 7}$ of the Code be so amended that every employee of the State, cuunty or city, be included in the provisions of that portion of the criminal law of the State for the canses set forth in that section of the Code, and which are made criminal thereby.

Also, that the Attorney General be instructed to institute proceedings against the Commissioners for re-locating the Seat of Government for the recovery from them of any bonus they may have received for their vote or influence in making such location, as any such bonus should have been for the benefit of the State and not for the benefit of said Commissioners.

\section{G. COLLINS, Chairman.}

\section{EVIDENOE.}

Thurgdar, February 11th, 1858.

The Committee appointed for the purpose of investigating certain charges of fraud in the location of the Capitol of Iowa, presented by certain citizens of Des Moines, Polk County, Iowa, to the House of Representatives of said State, met at their room in the Capitol-Mr. Collins in the chair.

On motion, ordered that subprenas be issued for the following witnesses, viz :-C. C. Van, W. C. Burton, J. C. Warner, Alfred Lyon, G. Holland, F. R. West, H. Lyon, H. Busick, F. Grimmel, Sen., James Campbell and Dr. Saylor. Subpenas were accordingly issued, summoning said witnesses to appear betore the Committee on the 13th instant, at 2 o'clock P. M.

On motion, adjourned to meet Saturday, February 13th, 1858, at 2 o'elock P. M.

\section{G. W. MoCRARY, Clerk, pro, tem.}

\section{SatUrDax, February 13th, 1858.}

The investigating Committee met at their room in the Capitol, at Des Moines, pursuant to adjournment-Mr. Collins in the chair. Present, besides the chairman, Messrs. Mahony, McCrary, Anthony and Melliser,- all the Committee. 
Francis $R$. West, a witness of lawful age, was introduced and sworn, and gave evidence, as follows: I can't say that I can substantiate the cannot say that I know of any question you may put to me. $\mathrm{I}$ by any bribe. I have some the Commissioners being influenced to protect. I can state that I indirect knowledge. I have myself to protect. I can to make the lobelieve they [the Commissioners] were influenced to main sum would cation here. I was told by third parties that ansioners. One of the place it over there, but not by the Com or two after the location, Commissioners proposed to sell me, a day or I don't think the title fifty lots for $\$ 10,000$. It was $\mathrm{Mr}$. Pegram. was vested in him. I think he was to get but the title was not in him. It was to be vommissioners. purchased. I did not learn that from either of the Com he said we I met him [Pegram] the day before the river, if we had done our might have had the Capitol over the river, duty. Mr. Baldwin made a proposition to procure I do not know on the other side of the river for some $\$ 20$ missioners, but I supposed that the proposition came from the Commission it did. I thought then that if the amount had been raised, that the Capitol would have been loc Commisother side. I do not know anything about anyitol. I did not sioners receiving any money for locating made by the other side want to know about it. The proposition maducement, I think of the river to give $\$ 200,000$ to the State as anderstand that the was not received by the Commissioners. 1 understand Commissioners treated the chairman of to man came to 1y. The night the Capitol was all up. Went down to Baldwin's room. Found him in bed. Pegram posed) was in bed with Baldwin.

was too late - that $\$ 40,000$ would not collows:

$O$. C. Van was called and sworn, and incements offered

I don't know that I know myself of the inducemo the Commissioners, if any. I have heard rumors. Ome of the Commissioners, [Mr. Pegram] said something about son to buy them was to get here, but I do not recollect whether he was to buy them or not. I understood at the time that he was to get them as a bonus. I think there were fifty lots. I don't know that he told me whom he got them from. A few days after the location was made, he told me he had sold his lots to Scott and Williamson. He did not tell me how he got the lots or who from. I inferred from his conversation that he was to get the lots tor locating the Capitol, but he did not say so. I don't know of any relation existing between Baldwin and the Commissioners. Baldwin was here and appeared to know what was going on, but he did not say he was an agent. I had a conversation with Baldwin-he stated to me that if the west side wonld raise, I think it was $\$ 50,000$, that he had no doubt but what the Capitol wonld be on the west side of the river. I understood the $\$ 50,000$ was to be given to the Commissioners. I believed him to be acting for the Commissioners. He did not mention the Commissioners.

Harrison Lyon called and sworn, and testified as follows:

If there was any fraud in the loeation of the Capitol, I don't know it. I have only heard from the other side of the river. I own part of the land where the Capitol is. I know nothing about it of my own knowledge. I never deeded a lot to $\mathrm{Mr}$. Pegram in my life. I sold Mr. Baldwin, I think, ten lots, abont the time the Capitol was located. The consideration for which I sold Baldwin the lots was, that he was to use his influence to get the Capitol on this side of the river. I let him have the lots to use his personal influence in favor of locating the Capitol. I did not intend the lots to go to the Commissioners. I do not know whether Baldwin gave the Commissioners anything or not.

The Committe adjourned.

G. W. MoCRARY, Clerk, pro. tem.

\section{Tuesday Evening, February 23d, 1858.}

The Committee, charged by the House of Representatives to investigate the charges of fraud, in the location of the Capitol of Iowa, met pursuant to adjournment.

C. C. Van was sworn and testified as follows:

I did not see any notes in the possession of Pegram. He told me he had them. I understood from $\mathbf{M r}$. Baldwin there were 250 lots at the disposal of somebody in case the Capitol was located here. I understood that Pegram sold some lots to Williamson and Scott. I do not know where he got the lots. I told him he had acted foolishly, because they could repudiate the notes. He thought they would be paid, as he could assign them to third persons. Baldwin told me he was to share in the profit, and my un- 
derstanding was that he got 50 lots. There were 250 lots set apart to be given to the Commissioners. Baldwin said he was to have a share. Crookham and Street were not to have a full share - such is my impression. It was thought less would do them. Baldwin told me he had got $\$ 1000$ that the Commissioners knew nothing about, in addition to the 50 lots. He did not tell me who from. When I caine here I found out from Baldwin that there were 250 lots to be given to the Commissioners. He asked me what we could give on the other side. The 250 lots were estimated at $\$ 10,000$. At that time Baldwin said he was in favor of the west side of the river, and said he thought a majority of the Commissioners were also, and that he thought $\$ 50,000$ would secure it. We determined that wo would not give that amount to the Commissioners. Before I h ard the Capitol was located, the people on the west side raised it subscription of a large amount, near $\$ 100,000, \mathrm{I}$ think. I know nothing about any of the Commissioners except Pegram, $\mathrm{He}$ told me this,--that he had made his mark at $\$ 10,000$, and they wotild have to come to that. $\mathrm{He}$ asked me why they did not come down, and said that $\$ 10,000$ was nothing. I have had no communication with any of the Commissioners besides Pegram. Pegram told me the notes he had received were made payable at Council Bluffs, and since then he has told me that they were paid. Pegram said there were 250 lots and that he was going to have 50 lots. My impression is that Goodrell was all the time in favor of this side.

The investigating Committee, charged with the investigation of the alleged frauds in the location of the Capitol of Iowa, met at their room at the Capitol, when the following proceedings were had.

Present-the chairman and all the members of the Committee.

F. R. West was sworn and testified as follows:

I cannot recollect anything more than I have stated in my former examination. Mr. Pegram, perhaps Goodrell, was here three or four days before the location was made. It appears to me that $\mathrm{Mr}$. Baldwin told me that $\$ 50,000$ would locate the Capitol. I will not state positively. Various sums, from $\$ 20,000$ to $\$ 50,000$, were named. I recollect distinctly Baldwin said to me, when I had a conversation with him in the night, as I said before, that $\$ 40,000$ would not change the location. I met Mr. Pegram a day or two after the location, and my impression is that he said we fellows on the west side would'nt do anything and therefore we had lost the Capitol. It might have been Baldwin but I am pretty not certain Pegram. I want to have you nnderstand that I am If it was'nt Pentemen made that remark to me. It it was'nt Pegram, Pegram was present. I know nothing about cept from hearsay.

Adjourned till 9 o'clock to-morrow morning.

E. C. Baldwin sworn. I don't know anything positively. I don't think they are correct. I do not recollect of saying to Lovell White, \&c. I got ten or fifteen lots which I understood were from Lyon. I supposed they thought it was for my influence. I considered it so. I met Captain West when I first came here. $\mathrm{He}$ said he was appointed to see what influence I could bring to bear. He offered me $\$ 20,000$ if I conld get the Capitol located on the - other side. I did not understand that the Commissioners were to get any lots for locating on the east side. I understood that a number of lots were appropriated for the purpose of getting influence. I do not know that the Commissioners ever received any lots except from rumor. I came here to make some money out of the matter. I found that the people thought that I had a great deal of influence with the Commissioners. I did not liear the Commissioners say anything about the lots to me. I- did not tell any of the Commissioners what offers I had received. I did not 4. know that what I would say to the Commissioners would have any influence. Mr. West came up to the room where I and Mr. Pegram were in bed and said he would give $\$ 50,000$ for the vote of one Commissioner. Mr. Pegram told me that he wanted to buy some property over here and that he had come over prepared to do so. I heard that some notes were sent to Couneil Bluffs. I have had conversation with Dr. Brooks, Dr. Shaw and Mr. Williamson. I did not give the Commissioners any lots, nor anything else. I did not make propositions from side to side. I did not hear of any lots that were to be given to the Cominissioners. I never told anybody that I had got $\$ 1000$ since I had been here.Pegram and $I$ came over together. We both came with money to invest. It was understood that I was to have the knowledge of the location after it was made and before it was made public. I should judge that the people thought that I would give something 
to the Commissioners from the liberal offers they made to me. If the Commissioners had been disposed to take money they could have received a large sum. I found a majority of the Commissioners were in tavor of the east side of the river. The offer that was made by the other side of the river was not made until after the location was made, and it was nothing more than blank paper. I heard them say that they would give ten acres of land to the State. The Commissioners get more land for the State here. I think there is some 32 acres. They objected to the land on the other side of the river for several reasons. The streets could not be laid out and the ground was broken. I heard that Pegram was to get some lots. ' I don't know who told me.

\section{February 25th, 1858, 4 o'clock P. M.}

The Committee met pursuant to call of the chairman.

Hall appeared for Goodrell and Wells-Kasson for the memorialists.

Hall presented the paper hereto attached and marked "D."

Lovell White was sworn and testified as follows:

Question. Wus you a resident in Des Moines during the years 1855 and 1856 ?

Answer. I was.

Q. Were you at this place at the time the Commissioners, were here to locate the Capitol under the act of 1855 ?

A. I was.

Q. Did you see the Commissioners while they were here for

that purpose?

A. 1 did.

Q. State your knowledge of any propositions made to the Commissioners, of land to be donated to the State through the Commissioners.

A. In regard to that: about the time of the location of the Capitol, there was a paper got up and numerously signed by citizens of Fort Des Moines to give a donation of land in consideration of the location of the Capitol.y The matter was agitated on the morning of a certain day, and the subscription paper, written I think, by myself, was circulated on which was subscribed some $\$ 70,000$.
Q. Dox you know where the original paper is?

A. It was left with the Commissionerser of ?

Judge Hall objected to any question concerning the paper.

Kasson gave the Commissioners notice to produce the original paper.

A. I have not seen it since. This paper which $I$ hold is a copy of the original paper made by me at the time. (Attached and marked "A.") This paper was circulated in the forenoon. I was acting in the matter myself while it was being circulated. Jewett was authorized on the part of the citizens to come over and offer to the Commissioners $\$ 200,000$ in land, in consideration of the location of the Capitol on the west side of the Des Moines river. That notification was forwarded. I saw it in the hands of the Commissioners. This was in the morning. In the afternoon I, with Jewett, came across the river to the house of Harry Griffith, - and there we found the Commissioners in session. // I asked if they were in session. They' said they were, and referred me to their chairman, Mr. Street. I asked Street if they had decided on a location of the Capitol. He said they had not. I asked if they were willing or desirous on behalf of the State to receive propositions from the eitizens of Des Moines. He said they were. I asked if he had received a notification from Mr. Jewett. He said they had. This paper I think is the same in substance as that. It is not in my hand writing. (Attached and marked "B.") This

> paper is the same in substance as the notice of which I enquired if they had received it, and it. was shown to me by the Commissoners. I then told Mr. Street and the Comnissioners, that the citizens were prepared to make their word good, and had sent over a subscription paper on which was subscribed the amount given in the paper marked "A." I further told them there would be other subscriptions made to the amount of the proposition- $\$ 200,000$. I showed the Commissioners the subscription paper, and saw them read it one after another. I,then asked them if it was desirable or would be in any way effective to make up the amount of the subscription to $\$ 200,000$. They answered that a subscription paper from any point would receive all the consideration to which it was entitled. I then asked if they would give us time to raise the subscription to $\$ 200,000$. They answered that we might have all that day-there would be no location that day. It was stated that the next morning they would receive anything we had to offer. I 
do not recollect the date except from the date of these papers, which is April 25th, 1856. It was the same day of the date of the papers. I went back on the west side on the same day and interested myself in getting further subseriptions. In the evening of that day we heard a rumor that the Commissioners had located the Capitol. On hearing that rumor, just atter tea, I went to Jewett's office, and with Jewett went to the room of the Commissioners and presented this paper. [Attached and marked "C."] It is additional subscription to the amount of $\$ 30,000$. On presenting this paper I asked if they had made a location of the Capitol, telling them I had understood they had. They answered that they had provided they conld agree with the holders of the land upon terms. I asked why they had hastened the location and said if we had had a little further time we should have completed the subseription of $\$ 200,000$. They made no particular answer-only said they had discharged their duties. Nothing further happened at that meeting. Dr. Brooks, J. M. Griffith and Thomas Mitchell eame in at that time, or I met them in the passage way. Nothing.was said only that the location was made if they could agree on terms and that it was unnecessary for us to make any further effort to get subscriptions to locate it on the west side. I knew the Commissioners. These remarks were made to them. This was all on the same day and evening. The Commissioners intimated that they wished no further discussion of the matter.

Q. What was the character of the /subscribers to the paperwere they property holders?

A. I think they were all good for the amounts subscribed by them.

Q. Were those subscriptions made in good faith?

A. They were as far as I know.

Q. Was the ten acres mentioned any part of the $\$ 200,000$ ?

A. It wasnot. The ten acres were to be given beside the $\$ 200,000$.

Q. State whether any person protessed to you to be acting for the Commissioners! [Objected to by counsel for Commissioners.]

Q. [By the chair.] Did you hear any one say that they were acting for the Commissioners ?

A. I did.

Q. Who was it ?

A. John Baldwin.
Q. State whether or not during the presence of the Cornmisioners in Des Moines for the re-location of the Capitol, and while the location was pending, you had conversation with a person professing to aet for, or represent the views of the Commissioners respecting the official acts of the Commissioners.

Objected to by connsel for Commissioners ou the ground that it calls for hearsay evidence. Overruled.]

A. During the time of the pendency of the location of the Capitol, and while the Commissioners were here, $\mathrm{I}$, in connection with others, acted for the citizens of the west side. Some two, three or four days prier to the location of the Capitol, John Baldwin, or the $\mathrm{Mr}$. Baldwin here, was introduced to me. He stated to me that he was authorized to act for Mr. Pegram and Mr. Street in the matter of the location of the Capitol. He had previously, to my knowledge, had conversation with my associates; therefore the subject did not come up as a new one. He told me he would secure the location of the Capitol for $\$ 20,000$, guarantied to him in the event it was located on the west side. He said it was the desire of the Commissioners to locate it there as the record would show better, and they would locate it there if they could do as well by locating it there. I had discussions with him at various times-almost every day. On the evening prior to the location of the Capitol he told me that the matter could not be delayed longer -that Crookham had come and he must make arrangements with some one at once. He said that it was highly important that the location should be upon the west side, and he would secure it for $\$ 15,000$, if guarantied to him. He could get more than that from the east side, but it would be in property and he wanted to make it a money transaction, if possible. For my people I did not accept any of the terms. The next conversation $I$ had with him was in the afternoon of the day on which the location was made, between the times I visited the Commissioners. He told me that he had agreed to locate the Capitol on the east side of the river. I asked him if that determination could be changed by any consideration, He said it could not. It was a bona fide agreement between himself and those with whom he acted. I asked him if he had any objection to my speaking to Pegram or Street relative to the matter. He said he had not, but it would be of no use-that they would hold no communication except through him. He said he bad closed the trade. He had done better than he offered to de 
on the west side. Baldwia was not present at the time of meeting
the Commissioners. It was in the afteroon of the I carri $d$ the suluscription in the afternoon of the day on which win told me he lat before the second. I had a little conve. It was after the first and after the location of the Capitol conversation with Mr. Pegram lots which were on the east side. He said he wished to sell some of lcts and would sell them said he had quite a number

The Committee then adjon time.

February 26th [Signed.]

\section{S. SIBLEY, Clerk.}

\section{February 26th, 1858, 7 o'clock P. M}

The Committee met pursuant to adjournment.

The memorialists and ex-commissioners appeared by their res-

Cross examination of Lovell White.

Q. How long before the location of missioners meet?

Crookham's arrival. I think he there was some delay in Mr. tion. It might have think he arrived the day before the loca-

Q. How long before the days before.

A. I do not know.

Q. Which of the

A. Mr. Pegram Commissioners did you first see?

Q. How long before the first I saw to know him. Pegram?

A. I could not say precisely. I think

Q. How long after the Commissioners three or four days. before you got up the first subscriptioners had all arrived was it Commissioners on the $22 \mathrm{~d}$ of $A$ ription which you presented to the

A. I think it was one or April, 1856

ing of the $22 \mathrm{~d}$ of April.

Q. Was that subscripti

missioners or either of them got up at the instance of the Com citizens on the west side?

A. As far as I know, at the instance of citizent on the wost side.
Q. Before that subscription was got up had you not heard $\mathbf{s}$ ramor that the Capitol wa located on the east side of the river?

A. No. Not otherwise, except that I had heard that Jobn

Baldwin had stated that the Capitol was to be located here,

Q. About what hour in the day was it that you presented the subscription at H. H. Griffith's ?

A. Immediately after dinner - between one and two o'ctock.

Q. Were all the Commissioners present at H. H. Griffith's at the time that subscription was presented to them?

A. They were-or at least they were introduced to me, five of them, as the Commissioners, and I afterwards knew them as such. Seeing them afterwards and knowing them to be the Commissioners, I recognized them as the persons I saw there.

Q. Was not Mr. Street sick, lying on the bed at that time, at H. H. Griffith's ?

A. He was, with his clothes on.

Q. Were not the other persons you saw out of doors sitting ander the trees in the shade?

A. They were not. They were all in the front room in H. H. Griftith's house?

Q. Were not Mr. Goodrell and Guy Wells sitting out doors at the time you went there; did either of them go into the house while you were there?

A. They might have been when we approached the house: but if so they went into the house for they were all present when I had conversation with the Commissioners.

* Q. Did you not hand the subseription paper to Mr. Wells when they were out of doors? did not Wells and Goodrell examine it and tell you to show it to Street in the house on the bed, and was there any person present in the room except Griffith and his lady at the time in the room?

A. My recollection is that the paper was not shown at all out of doors-that on making known the nature of my business in the room I was referred to $\mathrm{Mr}$. Street, who was lying on the bed-that I gave the paper to him - that it passed from hand to hand to all the Commissioners-that neither Mr. Griffith nor his lady were present - that Mr. Griffith I saw standing in front of his house at the fence-that Mr. and Mrs. Griffith might have come into the house during the time I staid there, but if so they made no stay.

Q. With whom did you converse while you were in the house? 
A. With Mr. Street particnlarly, but more or less with all the Commissioners.

Q. Was it not said publicly to you that the location had been

msde if the parties made conveyance of the land?

A. It was not in any manner whatever.

Q. Did you not go with Mr. Griflith up to', the public square
were the surveyor was surveying the land to examine it time?

A. I did-to the present grounds or near:them.

Q. Who was engaged in surveying the land at the time you were there?

A. I do not know-there were a number of persons about the Q. How do not remember who. I noticed no one surveying.

Q. How long did you remain where the surveying was going on ?

How long an the grounds some half hour perhaps.

before you heard the river

A. Just after dark I think

was located.

Q. Were all the Commissioners at the Demoine Honse when
on saw them that evening?

A. I think they were, but I will not state positively. I think

Q. Cere not when I went but I waited till they all came in, I think. night?

A. I am very confident he was.

Q. Are you as certain that the was on that side as you are that you had the conversation you have related?

A. I would not speak as definitely of the presence of the Com missioners in the evening as in the afternoon. I wonld not state that Street took part in the conversation that night wonld not state Commissioners were there if not allion that night. Most of the

Q. In what room in the

conversation? A. It was a front room over the dining:hall,"and the first, sec-
ond or third from the strairs.

Q. Were all the Commissioners that you talked with that night

A. They were.

Q. How long did you remain in the room with them?
A. Perhays ten minutes.

Q. Was not the subscriptions, a copy of which you presented hore, at the time they were got up intended as a more matter to make capital of, and with the understanding that they were never to be paid?

A. I signed the subscription in good faith myself and heard no one make any statement that they did not.

' $Q$. Who acted as the agent in procuring these subscriptions?

A. I did to some extent, and there were other parties. I cannot say who now.

Q. Who owned the square that was proposed tu be given to the State npon which it was proposed to erect the Capitol buildings on the west side?

A. Francis C. Grimmel and Richard Holcomb.

Q. Were those persons here at the time the Capitol was located? A. I cannot say positively - I think they were. They had ame days previonsly executed deeds of the ten acres and delivered them to Capt. West. I saw them.

Q. How far is that square from the river?

A. About five eighths of a mile.

Q. How far from the junction of the two rivers?

A. About three-fourths of a mile, I think.

Q. How is this ten acres marked on the map?

A. I never compared the deeds with the map, nor do I now recollect the description of the land in the deeds,- - but I understend it to be at the north-west corner of Grimmel's addition.

Q. How does it lie in reference to your addition?

A. It is a little north-east from mine.

Q. How far from your addition?

A. An eighth of a mile, in my judgment.

Q. Did the Commissioners go and examine this land?

A. I understand they did. I do not know of my own knowledge.

Q. In getting up your subscriptions was there any property described or indicated other than the ten acres that was to be given to the State?

A. There was no other property described that I remember of.

Q. Do you know that the persons who subscribed had property to give?

A. I know that most of them had, and at the time of making the subscription it was my impression that all were good for the amounts subscribed. 
Q. Was the subscription got up to be given to the State as a

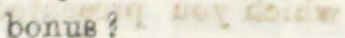

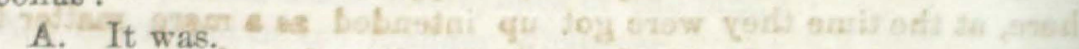

Q. Where was the property of these subscribers situated that they were to give?

A. There was no statement made as to that. They were to give such property as they had.

Q. This property was then given as a bribe to the State and not to the men?

A. The land was offered to the State in consideration of the Jocation of the Capitol.

Q. Were there any other subscriptions got up on the other side other than those you have described?

A. With the presentation of the two subseriptions we ceased all effort. We got np nothing further after that.

Q. Were not other subscriptions and notes got up there in con

sideration that it should be located on the west side?

A. There was.

Q. How much was so subscribed and by whom?

A. My impression would be that there was some $\$ 11,000$ or $\$ 12,000$ subscribed at one time.

Q. By whom was this sum subscribed, and in what shape was it fixed?

A. It was subscribed by most of the citizens on the west side of the river. As near as I remember the form was that they promised to pay to certain parties, of whom I was one, in case the Capitol was located on the west side of the river.

Q. Was it not collected in promissory notes?

A. It was mostly.

Q. Look at the petition and state how many of the signers were contributors to the fund you have last named.

Q. [By Mahony.] Was the fund of which yoa last spoke to be given to the State or to the Commissioners?

A. It was put into the hands of a committee to influence the location of the Capitol. There was no suggestion how it was to be used.

Q. Was you one of the committee, and how much did you contribute to that fund?

A. I was one of the committee. I contributed either $\$ 500$ or $\$ 1000$
Q. Was that fund so raised either directly or indirectly ever ffered to the Commissioners, through any person, or any part thereot ?

A. It was not to my knowledge, unless the fact that that com ittee held consultations with John Baldwin in reference to price, could be called so offering it. As a member of the committee I received offers from John Ballwin, but have no knowledge of any direct specific offer being made him.

Q. Was not that fund raised for the purpose of being paid over Commissioners and used as a bribe to get the location on the west side?

. It was pot absolutely in the hands of the committee, and wathorized to do with it just as I aw fit; would have been paid him.

Q. [By Mahony.] Was any portion of this money ever paid to the Commissioners?

inless the offer to Mr. Baldwin was so cousidered.

White in reference to intimations At the time of the [hest side, and fought the location I was deeply interested in the Capitol over therebattle to the best of my ability to locate the Capitol oner there as that-I signed a remonstrance against this investigation and did not solicit the privilege of coming here. I was compented to come here, wishing not to do so-that my intercsts wond suffer from this agitation, and am now adverse to its agitation.

or the Commissioners proffered the following quesThe cross-examination to the statements of John Baldwin, as out in the examination in chief, which he still objects to as Hecral and improper, and will maintain his exceptions thereto.

Q. When did you first see Mr. John Baldwin

A. Probably three dars before the location.

Q. How long after you tirst saw him, did you have the first conversation which yon detailed on yesterday evening?

as hamediately. I think he was introduced

o me to talk on the subject.

Q. Who introduced him?

A. Capt. West. 
Q. Was any one of the Commissioners present when he was introduced?

A. I did not at any time see Baldwin with the Commissioners.

Q. Where was it and what day was it you had the second con rersation with Baldwin in reference to the closing of the trade?

A. It was the evening prior to the location of the Capitol in wich he stated that the arrangement must be made with somebody for the location of the Capitol -it could not be delayed longer.It was in my office on Second street.

Q. Did Mr. Baldwin go to your office voluntarily or was he sent for by you or anybody else?

A. Mr. West's office was next door to mine but one, and during the time of Mr. Baldwin's stay here, he was in the offices a number of times each day. I am unable to say that he was or was not sent for-my impression is that he came there as he came before.

Q. Was that on Sunday or Saturday?

A. I can't tell the day of the week.

Q. Was not the Capitol located on Monday the 22d of April?

A. I don't know on what day of the week the $22 \mathrm{~d}$ of A pril fell on that year.

Q. Well, if the $22 \mathrm{~d}$ was on Monday, did the conversation take place on Sunday?

A. I don't remember of holding any conversation with Baldwin on Sunday-but it might have been so.

Q. At the time you had this conversation had you raised the $\$ 12,000$ or did you raise it afterwards?

A. We had raised it before, I think.

Q. When was it that you saw Baldwin and asked him whether the purpose of the Commissioners could not be changed?

A. It was after the presentation of the first subscription paper and before the presentation of the second.

Q. Abont what time in the afternoon was it that you had this conversation with Baldwin?

A. It was soon after my return from the east side of the river, or between that and tea time. I can't fix the hour.

Q. Who was present beside yourself and Baldwin when the conversation took place?

A. I think Capt. West, a part or all the time.

Q. What became of the notes and obligations gathered up in that special fund?
A. They were retarned to the partios giving them.

1. Was Gov. Grimes here during the spring or summer of that season?

A. I never saw Gov. Grimes to know him till about one year ago, when I was introduced to him at Iowa City.

Q. About what time did you see Gov. Grimes at Iowa City?

A. I left here to go to Iowa City the 25th of February, and I

y saw him soon after my arrival, about the first of March.

Q. Where was Gov. Grimes when you saw him?

A. He was at the Clinton House, Iowa City. Mr. Goodrell introduced him.

Q. Did you at the Clinton House, in Iowa City, state to Grov. Crimes that you believed the Commissioners locating the Capito acted honestly, and the imputation of bribery upon them was 3 slander, or words to that purport?

CObjected to by counsel for memorialists and objection sustained, Por the reason, as stated by Mr. Mahony, that it was impertinent, as the answer, whether in the affirmative or negative would be a contradiction to anything which the witness has already said. MeCrary dissented. The question might be asked for the purpose of impeachment whether it relates to testimony already given or not.]

Q. Have you contributed anything or promised anything towards hiring connsel to prosecute this case?

A. I have not.

Q. Where were C. H. and W. A. Poindexter, who signed the subscription, at that time?

A. They were represented here by William Baker, a brother in-law, who had charge of their property, which was in Keene and Poindexter's addition.

Q. Who subseribed per Barlow Granger?

A. It was for Lorenzo Bird, of Missouri.

Q. Do you know anything of the authority this party had to make this subscription?

A. I have bought property of Barlow Granger, as attorney in fact for Lorenzo Bird. I know nothing about Baker's authority.

Q. What do you know of J. A. Story's circumstances?

A. He owned quite a tract of land north of Grimmel's addition and still owus some. 
DIRECT EXAMINATION.

Q. What was the value per acre of the land now known Capitol Square prior to the location of the Capitol there?

A. I cannot fix the valne of the property on this side of the An the day the location was made there was ither nine or thirteen acres in the north tract, now known as Stewart's addition, sold for $\$ 150$ per acre. Prior to that time it had been estimated to be worth $\$ 100$ per acre. This was sifuated in the same half section and was a part of that tract and was an undivided interest.

Q. [By Mahony.] Was the subscription to be made to $\$ 200,000$ and was that guarantied to the Commissioners for the State?

A. The first proposition is in the notice by Jewett. The subscription papers were forwarded as evidence of good faith. It was understood that the sum of $\$ 200,000$ was to be made up. I do not recollect of hearing the matter discussed, whether if any part of the $\$ 200,000$ was not collected from the parties it shonld bet made up.

The Committce adjourned to March 1st, at 7 o'clock P. M.

Signed.] S. SIBLEY, Clerk.

Mondax, March 1st, 1858, 7 o'clock P. M.

The Committee met pursuant to arijournment.

Judge Hall and J. A. Williamson for the Commissioners-D. F Miller for the memorialists.

W. C. Burton being sworn, testified as follows:

Q. Were you residing at this eity at the time the location of the Capitol was made, and if you were state all you know abont the acts of the Comm.issioners in regard to its location?

A. I was. On the $22 \mathrm{~d}$ of April, 1856, aceording to the date of the subscription papers, I came with G. Holland to J. M. Griflith's with a notice to serve on the Commissioners, - that the proposition was made in the notice that we were about to raise a subscription of $\$ 200,000$ for the State, provided the Capitol wa located on the west sidè of the Des Moines river. We saw some two or three of the Cornmissioners at Griffith's and I believe that Mr. Wells was there at the time, and I believe two or three others. We told them our business. They told us that Mr. Street was over at H. H.
Griffith's and we had better go over and see him. We went in and he was lying on the bed with his back to the door, with his clothes on. We passed the time of day and told him what our busifiess was and served a notice on him by griving him the notice myself and took a eopy. We asked him it they had made the location. He said they had not. We asked him if they would take our proposition under consideration, and give ns until tomorrow morning to complete the subseription. Part of the subscriptions were made and we wanted till then to complete it. $\mathrm{He}$ stated there wonld be no location till 9 or 10 o'clock next day and that they would receive any offer and take it under consideration, which we might make. That is all the conversation $I$ had with the Commissioners.

Q. When did you first hear the location was made? in stated, and in refurning lome Imet Messrs. White and Jewett on the east side of the river coming over with the snbscription.

Q. Was that subscription of $\$ 200,000$ made in good faith so far as you know?

A. It was to the best of my knowledge. Mine was. I was on the subscription paper. It was on the evening of the same day that I heard a rumor that the location was made, but nothing reliable.

Q. Do you know anything abont any grotind being offered on the West side of the river for the Capitol, in addition to the $\$ 200,000$ ?

A. Nothing more than what was contained in the notice by Jewett.

$$
\text { DROSS EXAMINATION BY HALL. }
$$

Q. Were you one of the getters up and signers of the memorial presented to the House of Representatives?

A. I was.

Q. Have you contribnted to a fund to pay comnsel to aid in this investigation?

A. I have not, but expect to.

Q. Have you directly or indirectly made any promises conditioned on the success of this investigation?

A. I have made a contract with an Attorney to attend to this business.

Q. Is the contract conditioned in any part? 
A. It is not.

Q. Is there not a condition in some part with some of the counsel?

A. I have made a contract with Mr. Kasson. I am to pay him a certain amount, and if it takes more time and trouble than we are aware of, he leaves it optional with me to pay him what more it may be worth.

Q. Was this contract made before the memorial was presented to the House of Representatives ?

A. It was made aftewards.

Q. Is there not a contract expressed or understood between yourself and others of the memorialists and connsel, that if a state of facts can be proved to remove the Capitol to the west side of the river that a larger sum of money shall be paid them ?

A. All the cou act with Kasson I have stated. All that I have to say is, that $\mathrm{I}$ huse contracted with $\mathrm{Mr}$. Kasson and if more work is required than expected, he left it to us to pay more as can be agreed upon.

Q. [By Miller.] Do you pay me anything except as counsel before the Committee?

A. I do not.

Q. Were you a contributor to any fund except the $\$ 200,000$.

Objected to and the objection sustained by the Committee.

Q. What time was the $\$ 200,000$ subseription commenced to be got up?

A. It was commenced on the morning of the date of that sub scription paper.

Q. [By Mahoney.] Was there any rumor that the Capitol was located before that subscription paper was got up ?

A. We had not understood that a location was made. There were many rumors abroad.

Q. [By Mahoney.] Had you any apprehension that the loca. tion was made or had been made that day, or did you dread that it would be made on the east side?

A. We had some fears that the location would be made on the east side. We had fears that the location would be made on that day, or some day soon, on the east side, from the rumor we had heard.

Q. [By Mahoney.] Are you certain that you did not hear that the location was made before the subseription was got up ?
A. I am certain I did not so hear.

Q. Who was present when you

Street?

A. There was no one present.

Q. Did you not learn that

square, and what time was it yout MeHenry was surveying out the

A. It was some days after that Gaw Goodrell on the square?

after that 1 saw him and Lyons on the gquare. next day or day

Q. How long

yon presented the subseription to Stroners been in session before

A. I don't recollect who came Street ?

here, or did not all come at once. first or last. They were not all

the river among citizens respecting the lotement on both sides of was not every exertion and appliane location of the Capitol, and zens on both sides of the ativer in and by citiCapitol ?

A. There was

to the location. The Commissionexcitement at the time in regard the time-some were. They werers I was not acquainted with at time. I think only two put up wen the east side the most of the and Pegram I think. pose there was.

Q. Do you not know that part otthe $\$ 200,000$ subscription w as

made withont any intention of its being paid?

as my knowled ression at that time was, and my own now is, so fa. paper but was subscribed in not one dollar subscribed on that if the location had been in good faith and would have been paid as I was acquainted with the on the west side of the river. So far time I think they were all able to

Q. Was it not got up as a to pay their subscriptions.

mately used as they are now nsing it, or with a view to be ultiCapitol ?

A. It was got up side of the river, up as a last resort to get the location on the west the east side, and not receiving fommissioners made the location on would be an evidence that the for the State that amount, that that

Q. [By Mahoney.] Wat do their duty.

duce the Commissioners to locate the 
20.

A. Other propositions were made, 0 v vere about to be made.

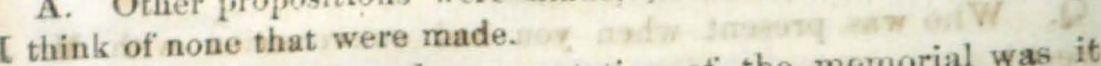
Q. How long before the presentation of the memorial was it got up ? Areulated on Thursday and presented on Friday.

r. Holland, being first duly sworn, testtied as follows :-

Q. Where did you reside when the present location of the Capitol was made?

A. At Ft. Des Moines, on the east side.

As one of the memorialists who have hired counsel, Mr. Burton claimed the right or privilege to be present during the inves tigation, which was granted.]

Q. Did you have any conversation with the Commissioners, who located the Capitol, or any or either of them before the Capitol was located, and if yea state how you came to have that conversation and what it was?

A. Sometime in April, 1856, I think the day before the location of the Capitol, I took a notice to three of the Commissioners. The notice stated that we on the west side would offer on the next morning, to the Commissioners, $\$ 200,000$ to the State for the location, if they located the Capitol on certain grounds, on the west side of the river. Mr. Burton went with me. I found two of the Commissioners at J. M. Griffith's. Wells and Pegram. I handed the notice to Mr. Wells, I think Wells and Pegram both read the notice. I think the only reply either of them made was that we had better see the President of the Board. We then went to H. H. Griftith's to see the President-Mr. Street. Street said he was unwell-he was in bed-and stated that the next morning he would come over and consider the proposition. There was nothing said but by Mr. Street. He said it was not too late to consider the proposition.

Q. Do you remember what Mr. Street said about the location being made or not being made?

A. I think he said it was not made.

Q. State whether you believed at that time that the $\$ 200,000$ wothld be made up at the time?
31

[Objected to by counsel for the accused and objection overraled.]

A. I did.

Q. Were you one of the subscribers? a th th

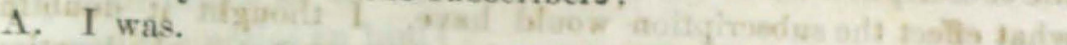

Q. Did you subscribe in good faith and did you believe the others subscribed in good faith ?

A. I can't speak as to others. I did myself and wonld have paid it very freely.

Q. Did you see eitlier of the Commissioners, especially Street, after the location, and what conversation had you with him?

A. I saw Mr. Street after that, and asked if he ever had said that the location was made before I served the notice on him. He said he had not so stated.

Q. [By Anthony.] Do you know of any money or other valuable thing being given to the Commissioners for the location of the Capitol on the east side of the river ?

2. A. I do not, except from rumor.

Q. [By Mahoney.] Had you any apprehensions when that subscription was got up that the Capitol was located on the east side?

A. I did not think it was located.

Q. [By Mahoney.] When you signed the subscription did you suppose that the Capitol was lecated, and did you sign with the expectation of changing the minds of the Commissioners if the location had already been made?

3 A. I did not suppose it was located when I subscribed, as Street told me the proposition would be considered before I subscribed. I did not consider that the Capitol was located. I supposed it was not, I signed to get it on the west side. There was a rumor that it was to be located on the east side.

Q. [By Mahoney.] Were you influenced by the rumors that the location w asmade, and did you come over to see the Commissioners about it ?

A. I don't know that I heard that the location was made, -only that it was about to be made.

Q. [By MeCrary.] Did you sign the subscription expecting that the Capitol would be located on the east side, and that the sub. scription paper would be nsed to disturb the location after it was made?

A. I don't think I thought of it at the time. I don't think it 
entered my mind-the thought of disturbing the location after it was made. I expected it would be located on the east side unless the subscription wonld secure it to the west side. I could not tell what effect the subscription would have. I thought it doubtfnl about the location. It might and it might not bring the location to the west side.

CROSS EXAMINATION.

Q. Was not that subscription got up after you heard the rumor that the Capitol was about to be located on the east side of the riv$e r$, and as a mere experiment to disturb the prior determination of the Commissioners and to be used to impeach their acts if they located the Capitol on the east side of the river?

A. I don't think I signed it with that view.

Q. Where did you meet White and Jewett on the return from Griftith's ?

A. Between Griftith's and the river.

Q. Did you come back with White and Jewett?

A. No, I went on.

Q. Did you subscribe the paper they took over or the one got up afterwards ?

A. I don't think I saw the paper until after I went over to notify them.

Q. If you signed the first paper did you sign it before or after it was taken over by White and Jewett?

A. I think Isigned it afterwards.

Q. Was that paper ever out of the possession of Street atter given him by White and Jewett?

A. I do not know that the subscription was given him by them except by hearsay.

Q. What time in the day did you make your subscription to that paper?

A. I do not know. It was atter dinuer when I came over to Griffith's.

Q. Did you or any other person designate any property to be given to the State?

A. I did not.

Q. Where did you see Street at the time of the second conversation with him ?

A. It was on the lower end of second street, west side.
Q. What time in the day and on what day?

A. I do not recollect. It was a day or two before he left town.

Q. Did not Street then tell yon the Commissioners had made up their minds as to the location of the Capitol at the time you served the notice on him?

A. He did not.

Q. Was there any other conversation beside that you have stated?

A. There was none.

Q. Was you a subscriber to any other fund than the one to be given to the State for the location of the Capitol?

A. I was.

Q. How much did you snbseribe?

A. I do not recollect.

Q. How do you know what day the Capitol was located?

A. Only from common rumor and seeing the the Surveyors on the hill with the Commissioners.

Q. Was not the Surveyor on the hill, making the survey, at the time you first saw Mr. Street?

A. Not that I know of.

Q. Had you not heard through White or some other person that they were making the survey at the time the notice was. served ?

A. I don't think I had so heard. I am pretty confident.

Q. Did you not hear it that afternoon?

A. I think I did.

Q. Are you acquainted with most or all the subscribers to this. paper?

A. I was acquainted with most all in town.

Q. In getting np these subscriptions was it not urged as a reason why the snberiptions should be liberal, that there was very little or no probability that they would ever be called upon to pay?

A. I did not get up the subscriptions. I could not say positively. I think I heard the remark made that they would have the subscriptions to pay. I could not say it was by those who took the subscriptions.

Q. Was not that the folling on the west side at the tims?

A. I condi not say what was the generai iccing. I suppose some thought it would be located on the west side and they wonld have the suberiptions to pay. 
Q. Was there not a good deal of excitement !

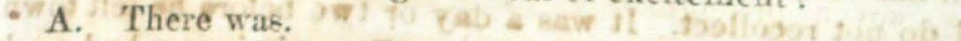
Q. Where was the grourd upon which the Capitol was to be located to nake the subscription binding?" of es proin wis to be

A. There were two tracts proposed. The notice did not desig. nate any thing more than ten acres. One was where Dr. Grim. mel's new house now is, and the other was beyond tliat. Wrim

Q. How far from the river? A. Abont a half a mile-about three fourths of a mile trom the
junction.

Q. How far above the fork is the nearest point of the river to

A. From Coon River north about half a inile and a little west. The witness pointed ont the two proposed lots on the map, and said the land at that time was not sub-divided intolots, and that EXAMINATION RESUMED.

Q. On what did you base the doubts you have expresseed as having at the time in regard to the location of the Capitol on the east side?

A. My doubts were raised by remors and not from what the Commissioners said.

Adjourned.

[Signed]

\section{S. SIBLEY, Clerk.}

Tuesday, March 2d, 1858 .

The Commitee met pursuant to adjournment.

Hall appeared for defense, - Miller for memorialists.

Dr. F. C. Grimmel, being first duly sworn, testified as follows : Q. Were yon at Fort Des Moines at the time the Commission ers were here for the location of the Capitol?
A. Yes,
Q. Did you own land at that time, adjoining the town?
A. Yes. It is now within the town.

Q. Did you take the Commissioners

part of it for the location of the Capitol on the land and offer any

A. Yes, I did. I showed the

would be snitable, and offered them all my lines and the spots that on the eighty acres I owned. The Commissioners came theresome six, seven or eight men came there. I I did not know the Commissionerb. a Those that were with me I told theylcould have any ten acres they would choose to put the Capitol on. Is I don't know how much it was worth per acre. I sold some for about $\$ 1200$ per lot since. o About four lots made an acre. 2 They told me they were the Commissioners. I understood they werel whis eighty acres was laid otitintor lots some time after that: II made the offer

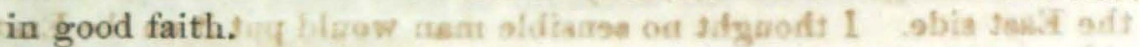

Q. How soon after you showed these lots was it before you heard the Capitol was located?

A. A day, or perhaps two days.

Q. Had you made $a$ deed to one of those ten acre lots to the State?

A. I did make a deed.

Q. Where is that deed?

A. I don't know. It sent it to Iowa City and have not seen it since. It was $x$ year or two prior to the location of the Capitol, and at the time the legislature was in session which passed the act for the removal.

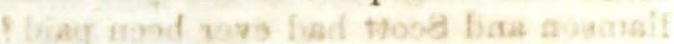

Q. Did you make a deed to the State when the Commissioners

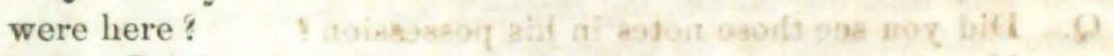
A. I did
Tie oh A

Q. Did you give that deed to the Commissioners or to some one to give them?

A. I don't know. It was put in R. Holcomb's hands. Holcomb was willing to give ten acres if the Oapitol came there.

\section{CROSS EXAMTNATION. $w$ oif Hoithagp}

Q. Was not Holcomb to take the ten acres from you, and he

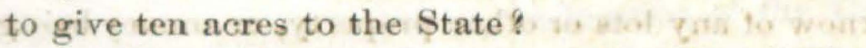

A. He was to give ten acres to the State if they wanted it. If twenty acres was taken from me for the State he was to give me ten acres; and if twenty aeres of his land should be taken, I was to give him ten acres.

Q. Who was this understanding with?

A. With Holcomb.

Q. How much did you subseribe to bring the Capitol on the west side?

A. $\$ 10,000$.

Q. Who brought the subscription to you ? 
A. I do not remember.

Q. Did you understand that ted an the east aide?

Q. Did you not believ. I did not know. That was to be settled. the East side?
A. I thought it was as likely to come the East side. I thought noely to come on the West side as on side.

Q. Did you sign thi and marked "E."]

Q. Is that the paper that paper. I think I signed it.

A. I think it is.

J. T. Baldwin, being duly sworn, testified as follows:

Q. Did Pegram ever tell you that the notes he had on Wil-

A. No, sir.

Q. Did you see these notes in his possession?
A. No, sir.

Q. Did he say he had such notes?

A. No, sir. He never told me he

Q. How much did you get for he had any.

location of the Capitol here for your influence in procuring the

This question the witnese the east side?

his private affairs.

Q. Do you know of any lots or other property, or ill

paid to influence the location of the Capitoperty, or money being

A No, sir. I did not see any the Capitol on the East side?

Q. Do you know of any Commissionet any deed or anything. ots on this side of the river?

A. No, sir.

Q. Do you know of any of the (ommisioners baying ang

on the East sitle of the rivap at thet tommissioners baying any lot

A. No, sir.

Q. Did Pegram tell you he had any lots on the Bast side of

A. No, sir.
Q. Did he ever tell you ?

A. Before we came here Pegram came into my oftice and said he had a proposition to buy some lots, and wanted to know if they would be cheap. I told him I thought they would.

Q. Was Mr. J. A. Williamson over to see Pegram before he came on to make the location?

A. No, sir. I did not see him.

Q. Did you come here to influence the Commissioners in the location of the Capitol?

\section{A. No, sir.}

Q. Did you propose to any person on the other side to procure the location on that side for a certain sum of money?

[Objected to.]

Q. Did you talk with the Commissioners about the location of the Capitol?

A. I did.

Q. What did you say?

A. I talked with all of thein a good many times. I was always in favor of the location upon the East side of the river, and when I talked with them it was to that purport.

Q. Do you know that Pegram got lots on the East side of the river which he disposed of afterwards to Williamson and others ?

A. I do not. I left immediately after the location was made, and never heard anything of his getting lots till long afterwards.

Q. Did not you know that Pegram got an interest in lots here,

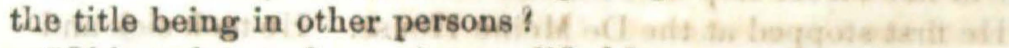

[Objected to and question modified.]

Q. Did not you know that there were 250 lots on this side of the river set apart to secure the location of the Capitol? Did not you know that a number of lots were appropriated here to influence the location of the Capitol ?

A. I did not at that time. During the winter that the act for the removal passed, I understood that some land was appropriated to defray the expenses of the persons going up to the Capital to lobby through the bill.

Q. Did you not hear that the promissory notes were sent to Council Bluffs for Pegram?

A. No, sir. I understood there was a note at Cassady \& Test's office, at Council Bluffe, for Pegram. 
Yov llat wave sil hicl of

Q. Did you and Pegram come here together 8 sw swits

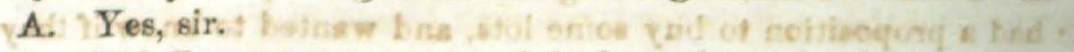

Q. Did Pegram get notes while here from any body for any

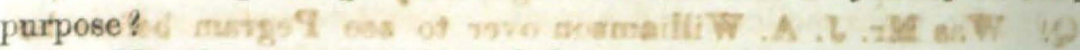

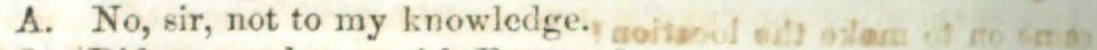

Q. Did you go home with Pegram?

A. What means did you ure to influence the location of the Capitol on the East side?

the Legisla:

A. I told them I thought it was the intention of the Legislabeen made there.

Q. Did you get money or property to use your influence to get the location on the East side?

A. I promised none to the Commissioners, and none was promised throngh me.

Q. Where did the Commissioners stop?

A. Some at the De Moine House. I think all stopped there.

Q. Did they stop on the East side?

A. They did most of their eating and drinking on the East sicle. They remarked that the people on the West side gave them the cold shoulder; while on the East side they were treated with more hospitality, and this treatment on the East side had some influence in the location of the Capitol.

Q. Dia not Street stop at Griffith's most of the time ? lif

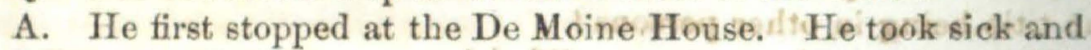
came over to Griffith's.

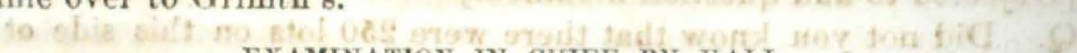
EXAMINATION IN CHEF BY HALL.

Q. Do you recollect the day the subscription was presented to the Commissioners from the West side?

A. I did not see it. I recollect of some of the Commissioners speaking of a subseription.:

Q. Who came up with it ?

A. I don't recollect.

Q. State what time in the day was the location of the Capitol made when it was made?

A. I think in the morning, shortly after breakfast.

Q. What measures did the Commissioners take towards sarveying the ground that morning?
A. I don't recollect. I think they were getting a surveyor.-

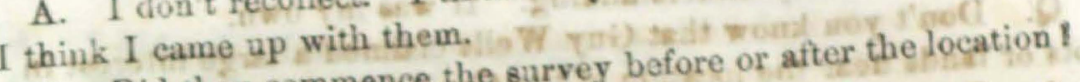
Q. Did they commence the survey before or after the location

A. I think after.

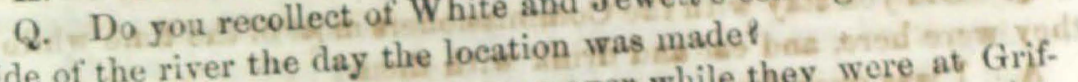
side of the river the day the location was while they were at Grif-

A. No, sir. Some person came orerno, whoch fith's. I don't recollect, who, ir inducement did you holl out to par-

Q. [By Anthony.] What inducement you conld influence the ties other than the Commissioners that you conia in Commissioners? 7 wing any proposition to apy parties.A. I don't recollect making any proposition to them. They Other parties offered propositions to me, the Capitol for sale. talked to me as though I had the location parties on the East side Q. Have you had conversation, with partiestion, and before tessince you were subpœnaed on the Capitoling titying before the eommittee?

A. I had conversation in regard to what I eane over here and

what could be proven by me.

Q. [By Mahony.] What was the character of youric.... of

tion with the Commissioners?

A. I could not state. I have not mens matters. other persens, and we talked on various mature of your conversation Q. [By Mahony.] What

with the Commissioners?

A. We talked about the various subjects of the, daythings. Q. [By Mahony.] Was there any conversation between you and either of the Capitol on the East side of the river?

A. + No, sir.

property here.

Q. [By Mahony.] Did you know of either of the Commissioners receiving or having any interest in lands or lots on the East side of the river, at the time the location was made?

A. No, sir. There were propositions to me individually.

Q. Did you understand that the propositions were for your own Did not for the commissioners, and that you were to keep influence and not was given? 
A. That was my understanding. It was my own.

Q. Don't you know that Guy Wells claimed a large interest in lots or lands near the location of the Capitol at that time?

A. I did not.

Q. Did you stay with the Commissioners most of the time while they were here, and eat and drink with them?

A. I was over there with them several times, not every time.

I was invited to tea with them several times.

Q. Did you not sleep with one of the Commissioners ?

A. I did.

Q. What understanding was there between yourself and the Commissioners?

A. I was to have the benefit of the knowledge of the location from one of the Commissioners betore it was made public.

Q. Did you exercise any influence with the Commissioners in consideration of offers made you?

A. I talked with Pegram many times about the location. I wrote to Pegram while the matter was before the Legislature, if he was in favor of the location of the Capitol on the East side. He wrote me he was. I helped to get him appointed.

Q. Were you to give the Commissioners anything for the knowledge they were to give you?

A. I was not. I gave them nothing.

Q. Did you receive information that there was to be a subpona for you before you got it ?

A. Yes, sir.

Q. Did it come in a letter?

A. I snppose it did. I got it from my brother, who lives at Council Bluffs.

Q. How soon after the information did you get the subpona? How soon after your brother got the letter did he tell you?

A. I don't know. They go to the office in the morning-I was away. I got it in the evening.

Q. Who sent that information ?

A. I don't know.

Q. Was there a suggestion that you had better go over into Nebraska for a few days?

A. No, sir.

Q. Did you see Pegram after you got the letter and before you got the subpona?
A. I did not. I say him, Pegram, after.

Q. What did you and he converse about?

A. He asked me if I was going on.' I said yes. He asked if I thought he would get a subpoena. I thought perhaps he might.

Q. At the time you and Pegram had this conversation did he manifest any feeling?

A. No, sir. He said, "let her rip."

j

J. B. Steroart, being sworn, testified as followș:

Q. Did you appear before the Mayor and Aldermen of Dos Moines City, some several months ago, to have a change made in the assessment of lots $\bullet$ the East side of the river that had been made to you?

A. I don't think I ever appeared before the Mayor and Aldermen when they were in session. I can say however that I requested one of the Aldermen-Tidrick, I think-and the Treasurer to see if the change could not be made. My reason was, the land had been assessed by the acre in one tract to myself and others. Several undivided interests had been conveyed to other parties prior to that time, some perl:aps a year before, and as the tax amounted to about $\$ 1,000$, I desired to have the change made so that I could pay my part, and not pay for all the entire interest or assessment.

Q. Was Mr. Wells interested in any part of the property you had so assessed?

A. He was.

Q. To what extent was he interested?

A. To the extent of ten acres, from the 20 th day of December, 1854, which was the date of the bond. It was not conveyed to him by deed 'till it was divided. It was conveyed since the first of September, 1857. He paid for it some time before-one halt on the 20th of December, 1854, and the other halt on the tirst of November following. The price he paid was $\$ 35$ per acre - a good price at that time.

Q. Where did that ten acres lay in reference to the Capitol?

A. It was an undivided interest in what is known as Stewarts addition.

Q. Was that land sold to Wells at the time of the passage of the act for the removal of the Capitol? 
A. It was during that session of the Legislature-a verbal agreement was made before, Q. How soon atter that was Wells appointed one of the Com-

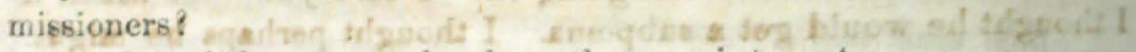

A. I don't know exactly about the appointment. if ofla if

Q. Was there any contingency in the verbal agreement ?

A. None. N

Q. Did you know, or was it not the talk before he was appointed, that he would be appointed?

A. It so, not more than a week or so. I think not.

Q. Did no one so state-no one from Fowa City?

A. I don't know that I beard his name mentioned.

Q. Do yon know of any other property that Wells claims to

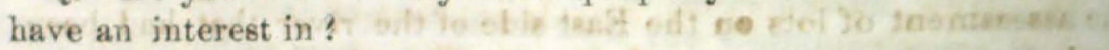

A. I do not.

Q. When the land was sold to him ald you suppose he would

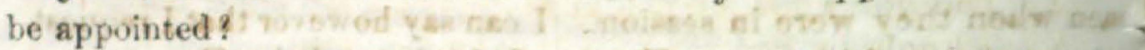

A. I had not the least idea of it. 1 it $\mathrm{T}-\mathrm{a}$ mir.

Q. Did you not expect that Wells wotld use his influence with

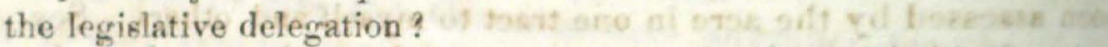

A. I did. I supposed it would result in that. ari tutivatur CROSS EXAMINATION,

Q. Did not Wells pay full price, and even higher than others who purchased interests in that land?

A. He did pay as ligh or higher than some land in the same tract sold for?

Q. Did Judge Wright pay as much as Wells? asw oll it

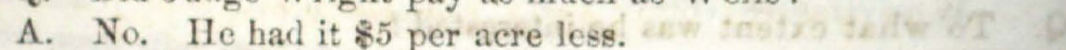

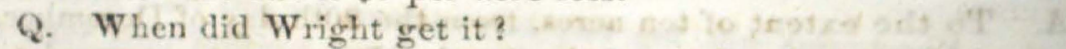

A. He got it about the time of the passage of the law.

J. A. Williamson, being duly sworn, testified as follows:

Q. Do you know of Pegram's receiving or having received any promisory notez, on or about, or soon atter the location of the Capitol?

A. I do.

Q. How much were the notes for?

A. There were some two or three of them. In all the amount was $\$ 10,000$.

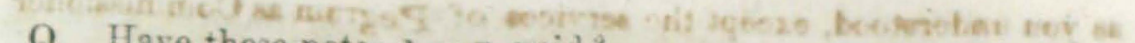

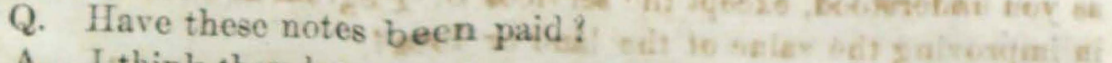

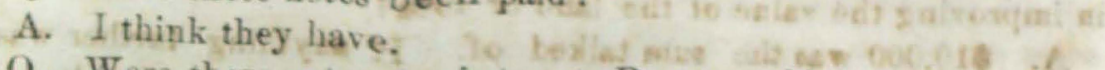

Q. Were these notes for interests Pegram sold in property on. the East side of the river?

A. Yes.

szinvib of

Q. Where dich the property lie?

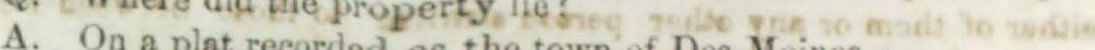

W. What plat recorded as the town of Des Moines.

Q. What was the number of lots that he sold? in otad l the

A. A bout fity I think.

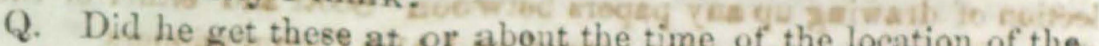
Capitol?

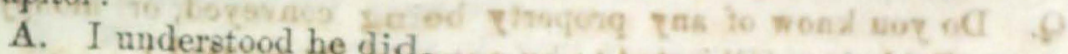

Q. How many lots had Street?

A. I don't know. I never had any conversation with him about it.

Q. Did you know he had any?

A. I know by hearsay only that he had lots. wex hicl s?

Q. Do you know of Wells having lots except the ten acres over here?

A. I heard Wells say he had purchased a lot of Scott, to build an office on if he should desire, on the bottom.

Q. Were yon one of the parties who purchased the lots of $\mathrm{Pe}$ gram?

A. Yes.

Q. From whom did the title come? saw wil f

A. I received my title from W. A. Scott, the yna w W .

Q. Who was the other party who purchased with you from Pegram?

A. W. A. Scott signed the note with me tor them.

Q. Who bonght Street's lots?

A. I know nothing about Street's lots.

Q. Is it in your knowledge that any other of the Commission ers than Pegram had any interest in lots or land here?

A. I don't know of any one's having any interest in lots or lands, directly or indirectly, here. I heard such things.

Q. Did you know the consideration Pegram gave for these lots?

A. As an Attorney I drew the papers for these lots, in which the consideration mentioned was $\$ 10,000$. I saw no money paid except to me as Attorney, for fees.

Q. Was there any money paid, or was there any consideration 
as you understood, except the services of Pegram as Commissioner in improving the value of the land or lots?

A. $\$ 10,000$ was the sum talked of. If anything further was mentioned it was in a professional manner which I do not choose to divulge.

Q. Did you draw up any papers between the Commissioners or either of them or any other person similar to those between $\mathrm{Pe}$. gram and Scott?

A. I have always drawn up Scott's papers. I have no recollection of drawing up any papers between Scott and either of the Commissioners or any other person and the Commissioners.

Q. Do you know of any property being conveyed, or money given to Baldwin. [Objected to by counsel for accused.]

A. If I have any knowledge about that it is of a professional eharacter. I wanted the influence of Baldwin and would have been willing to have paid him for it.

Q. Did you go to Council Bluff's to see Pegram?

A. I never saw Pegram till he came here. I went to Council Bluffs, but I did not see Baldwin.

Q. Did you know of Crookham's having any lots here?

A. I heard so. I don't know of whom he got them.

Q. Had you an interest in Scott's addition?

A. I had of ten acres.

Q. Was Dr. Shaw a partner in interest?

A. He was.

Q. Was any part of that addition sold to the Commissioners or either of them ?

A. Pegram stated he had bought fifty lots in that addition.

Q. Did you know of any attempts being made to influence the Commissioners in the location of the Capitol as now made?

A. I do. I worked steadily for it for a year and a half to get the location where it now is. I used all lawful and legal means to get it, including Chesapeake and Sardinian appliances, and any quantity of whiskey.

Q. Do you know ot any money or property being devoted to influence the Commissioners in making the location as now made?

A. I know I expended a good deal of money indirectly to influence the location here. I expended it in influencing public opinion-in traveling trom point to point, to secure this point as the best calculated to accommodate the most people of the State, and as the peint where more liberal donations conld be got for the State, and as a better town site, and where there would be more facilities for any person, who wished to get a lot in the Capitol, to get it at the eheapest rates.

Q. Were the Commissioners to have any interest in town lots; or land ?

A. I solicited persons to make such donations after knowing that similar appliances were being used by parties on the other side of the river. If ever such donation was made it was by myself, and would be a part of my private business, concerning which I decline answering any quettion.

Q. What was the result of your application to such persons?

A. I found one person who was willing to trust ten or fitteen

lots in my hands. That was all that were placed at my disposal.

Q. Have you any knowledge of applications of a similar kind being made to or for other parties to influence the Commissioners ?

A. No.

Q. Have you any knowledge that any of the Commissioners, except Pegram, received bribes or bonuses, or other thing to influence the location of the Capitol?

A. I don't know Pegram's notions about the location of the Capitol. I don't conceive it possible that the other Commissioners could be bribed if they did receive bonuses. I have every reason to believe, from their own convictions, that they believed this to 5 be the right place for the location of the Capitol. I don't know of any bonus being given to influence their vote or action. I don't know that anything was given Pegram to influence the action of his judgment.

Q. Did they receive any gratuity in lands, money or lots before or after the location was made?

A. I think it possible they might have had some presents given them after the location of the Capitol. I know some of them have property here, and I don't know anything to the contrary that they paid a consideration to Scott. I got up the papers and they expressed a fair consideration. I do not know anything to the contrary to there being a fair considoration paid.

Q. Who were tho puties to thase prosers?

A. I drew up a bond between Scott and Pegram. If boand himself to convey fifty lots. I think I got np no other papers between them at that time. 
Q. Did you hear any perzon say that he would give the Coanmissioners any botius to bring the location over here? act sat hat A. I don't recollect anything particularly about = that. ta $I$ have heard, and it was common talk, that wer would give anything to got the location of the Capitol. Q."W Were you interested in Pregran's lota got of Scott?

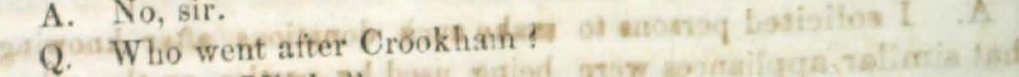

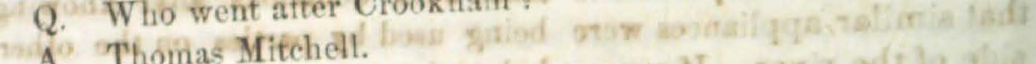

150 Where was he

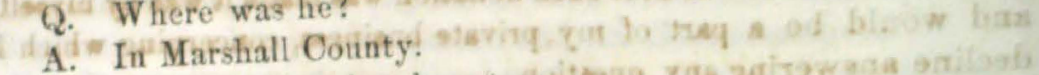

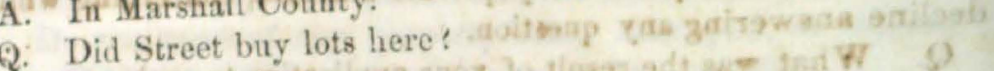

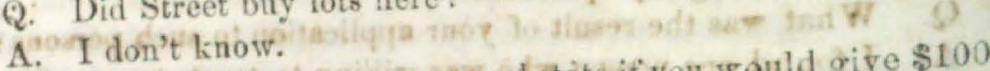

Q. Did Baldwin come to you and state if you would give $\$ 1000$ $n$ addition to the lots, he wonld seenre the location on the East

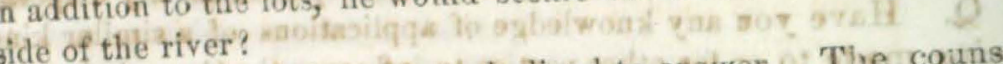
CObjected to, and the witness deelined to answer. The counsel for mernorialists modified his question.]

Q. Do you know of Baldwin's getting $\$ 1,000$ from others ?

[Objected to and the question moditied.

Q. What appeared to be the relation of Baldwin te the Com-

missioners while here?

Objected to, which the Committee sinstained, as not being direct-

ly pertinent to the istie.

Adjourned. S. SIBLEY, Clerk. [Signed.]

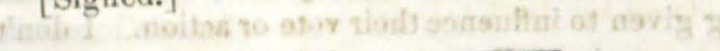

Мавсн $3 \mathrm{~d}, 1858$.

The Committee met pursuant to adjotrnment.

James Campbell, being dnly sworn, testitied as follows:

Q. Did you reside in this city at the time of the location of the Capitol?

A. Yes, sir, on the West side.

Q. Had you any conversation with the Commissioners, or either of them, at the time of the location of the Capitol, or soon after? And if so, state all that conversation, whatever it was.

A About a week after the location I had a talk with Crookham in regard to the location-don't know the exact words-not balf of it. We were talking more or less abont the location made, and next about lots. I don't recoliect of his saying how he got them, or how he paid for them $\rightarrow$ don't recollect/how many there were. I I understood him to say he had some lots aver there $\rightarrow$ the East side -and was going to have them surveyed before he went home. I think it was before he went home; It miglit have, been after he went home and came back.

Q. Were you well acrnainted with Croolshan at t

f as A. I was. I had been acquainted with him fon several yeurs.

Q. What was your reply when Crowham said he was going to have his lots surveyed off?

A. I think I said, if I were die I swowld have, them rean off and get the deeds before I left, or sometiling like, it. It may be entireIy different from what $I$ have stated. I did not charge my mind

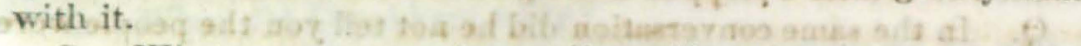

Q. What was your-understanding of how he got them?

A. I thought then for locating the, Capitol over on the East D side. He did not say so, nor speak of it in the least. I wish I knew more of it. I would tell it. I would like to blow it higher than the sky.

Q. Did you hear him say anything about any other of the Commissioners having lots on the East side?

A. I don't remember.

Q. Did you have any conversation with Crookham about any of the rest of the Commissioners?

A. I don't recollect. I don't think I did. $y$ These lots spoken $z$ of I understood to lay on, the East side.

Q. Do you know whether any of the Commissioners received anythirig in lots or money?

A. I do not. I did not hear from whem the deeds to Crookham were to come.

$$
\text { CROSS EXAMINATION. }
$$

Q. Where were you when this conversation took place?

A. In the third story of my building down at the point.

Q. Did not, in the same conversation, Crookham tell you he was looking for Charley Van to go over Coon river to survey land?

A. I think he was looking for a surveyor-don't know who,something was said about his-Crookham's-lookiag for a survey. or. Don't recollect anything about Coon river.

Q. Might not the conversation of Crookham have been in reference to land the Commissioners got for the State? 
A. That might have been. But I think he said he had got so many lots over there on the East side.

Q. Did not he tell you he was going over south of Coon river?

A. It might have been. I don't know. I don't recolleet.

Q. Did he not tell you he was going home as soon as he gót the survey and deeds ?

A. It might have been-think he did.

Q. Did not Crookham meet the surveyor and send hands to go on and survey on the other side of Coon river ?

A. I dont know-do not recollect.

Q. Did you understand that he got the surveyor ?

A. I don't recollect of seeing them meet-did not pay any attention to it after I stopped talking with Crookham.

Q. In the same conversation did he not tell you the people were foolish on this side for not donating for a State University?

A. He may-I don't recollect.

Q. Did you not at the time feel deeply interested in having the Capitol located on the west side of the river?

A. Yes. But this was after the location was made.

Q. Did you not feel disappointed and chagrined at the location over there?

A. I did. I did'nt think there was a disinterested man in the United States who wonld locate it on the east side of the river. I did not think they could locate it over there.

Q. Was it not McHenry, Crookham was looking for as surveyor?

A. It might have been. I don't recollect.

$$
\text { DIREOT EXAMINATION. }
$$

Q. When you had this convereation why did you say he had better get the title right before he left?

[Oljected to.

A. Only as it would be iny way of doing business.

Q. At the time of the conversation did you think the Capitol grounds had been surveyed?

A. I did not know.

Q. What fed to this conversation with Crookham?

A. I dou't reollect. I think it was about the Capitol-think I said we wonld have given more on this side than they gave on that- think I recollect asking how much they, the Commissioners, got over there for themselves. I don't know that Crookbam took it that way. I took it they got it for themselves-told him would have given twice that on the west side.

Q. When you said you would have given twice as much, did you mean to the State or to the Commissioners?

A. I hardly know-would have given to the Commissioners or to the State.

Q. What reason had you to think they would accept offers, or were in market?

A. Because I thought no reasonable, disinterested man could locate it over there.

Q. Did you not visit Crookham at Oskaloosa, to learn where he wonld locate the Capitol ?

A. I went to Oskaloosa. I was very anxious to learn which side he was in favor of-don't think I put it to him right straight.

Q. What did Crookham reply?

A. I don't think he gave any preference-thought he was as favorable to the west side as to the east side - think he said he had 2 not examined the east side-think he said my property was as good as in the Fort, and he would not change it let the Capitol go where it would.

The Committee then adjourned.

[Signed.]

\section{S. SIBLEY, Clerk.}

The Committee met pursuant to adjournment.

Parties appeared by their respective connsel.

A. M. Cassady, being duly swern, testified as follows :

Q. Mr. Cassady, I am instructed to inquire of you whether you had any conversation with any or either of the Commissioners about the location of the Capitol of the State since the location was made, in relation to his ownership of property at Des Moines City; if yea state who that Commissioner was you talked with, and what he said, and about what time he said it.

A. I had a conversation with Mr. Crookham. I think it was in the latter part of 1856 or early part of 1857 . We were conversing about the depreciation of real estate in the country./ $\mathrm{He}_{\mathbf{C}}$ told me that Mr. Mitchell and himself had an interest in property at or near Fort Des Moines, for which they had been offered from 
$\$ 5000$ to $\$ 10,000$, and that he was in fay of of selling. Mitchel considered the land would advance and was opposed to the salo.I think that was in 1857 . The amount would range from five or six thousand to ten thousand dollars-about cight thousand dollars. This conversation took place in Crookham's office. The cause of it was we were talking about the depreciation in the valtue of land - the conversation rose in that way. He and I had something to do in real estate then.

OROSB EXAMINATION. Q. Did not this conversation take place in the fall of 1857 , af ter the hard times had commenced and had began to depreciate? A. I will not state positively at what time, but think it was as early at least as the spring of 1857 , from the fact that $I$ had just returned from the east at that time, and I returned in the latter part of April. I think that was the time. It might have been before I left for the east.

Q. Was not this all a matter of joke and romance, and did not the conversation arise from your asking Crookham how much he made at or from the location of the Capitol ?

A. I think not for the reason that we were conversing on the depreciation in real estate and $I$ think there was no person but Crookliam and myself present at the time. I have joked with him in relation to the location but not at that time.

Q. [By Crookham.] Did I not say in that conversation a speculation of 61 acrès, I think, was offered to me, and Mitchell estimated that at $\$ 5000$, and Mitchell thought we had better go into it, and that it now conld be had for less than half that money?

A. I think the conversation related to an interest he (Crookham ) had that time with Mitchell, and as near as I remomber, his Ianguage was that Mitchell and himself had an individual interest at Fort Des Moines, for which they had been offered several thousand dollars, as I stated before-that Crookham was in favor of selling but Mitchell considered the real estate would increase-in value and was opposed to the sale.

asu Q. [By Mahoney.] Do yon know of any lots, lands or money being given to the Commissioners for loeating the Capitol?

oll A. I do not.

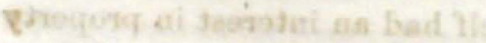

Thomas Mitchell; being duly sworn, testifies as follows:
Q. Were you here at the timst

A. I was,

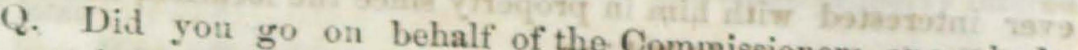
else, to bring Mr. Crookham in ? A. I went at the suggestion of certain others $=$ Dri Brooks and

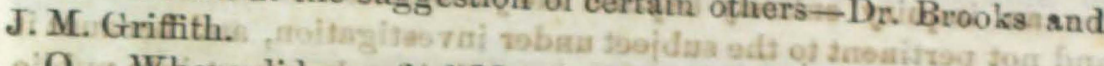

5.Q. Where did you find Mr. Crookham by som

A. In Marshall County, Marshalltown. bovomens li , betos zace

Q. Did you return with Croollamen. to

A. I did.

Q. Do you know of Crookham's buying any propenty herestort he returned ? a bire

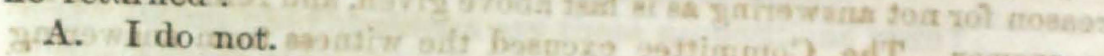

Q. Do you know of Crookham's ever buying any property abont this town?

A. I think I do. $\mathrm{He}$ may have owned some in this copnty.

Q. Who did he get it from?

2 A. I don't know.

Q. Where does it lay?

A. I don't know.

Q. How did you understand that Crookham owned property here?

A. I think I heard from him.

Q. When did you hear it from him

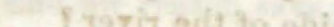

A. I think at ditferent times before and since the location.

vQ. Does the land lie on the east or west side of the river?

A. I think on both sides.

Q. Are you interested with him in any property in this county?

A. No, sir.

Q. Were you ever interested in any property in this county with him?

[Objected to and the objection sustained. This question the witness declined to answer and the counsel for the memorialists put the following: ]

and Q. Was Crookham ever, or is he now interested in any property in this connty with yon?

A. He was not interested with me in any property prior to the loeation of the Capitol.

[The witness declined answering whether he (Crookham) was 
ever interested with him in property since the location, and filed the following reason, to wit :-

"The witnees objects to answer the question because it embraces an inquiry entirely beyond the jurisdiction of the Committee and not pertinent to the subject under investigation, and because it may send, if answered affirmatively, to bring deponent into public scandal."]

Q. How long is it since Crookham became interested in the property which you declined answering about?

[Objected to but not sustained. The witness then filed the same reason for not answering as is last above given, and refused a further answer. The Committee excused the witness from answering on the ground last stated, as coming within the statute exempting witnessess from testifying in certain cases.]

Q. When you went to see Crookham did any one authorize you to make any arrangement in regard to the sale, trade or conveyance of any property to Crookham, and if yea did you give Crookham information of that fact?

A. I think not. I might have told him there was a good deal of property here to sell-might have made such a proposition as that.

Q. Did you tell him there was any property to sell on the east side of the river?

A. I think not. I may have.

Q. Do you know of Crookam's getting any interest in property here at or about the the time of the location of the Capitol here?

A. I do not.

Q. Do you know of his getting any interest in property on the east side of the river since the location of the Capitol ?

[Objected to, but not sustained. The witness declined to answer the question in full, for the reasons stated in his refusal first above written, and proceeded to answer as follows : ]

A. I don't"know as he has or ever had any legitimate title or interest in a part of land on the east side of the river. He has property in the county, I have understood, but I don't know where it is located.

Q. At or abont the time, or soon after the location of the Capitol, did you hear Crookham speak about any interest in property he had here?
A. Yes, I think I heard him say he had some property offered to him.

Q. Who offered it ?

A. I don't know. He had several propositions of the kind of fered him.

Q. Were these propositions made just before or immediately after the location?

A. I cannot say. I think they must have been before.

Q. Were they made after you came with him (Crookham) from Marshall county?

A. I think not-think they were made before.

Q. What did Crookham say these propositions were?

A. I think they were in relation to property on the west side.

Q. What did he say about property being offered to him on the east side?

A. I never heard him say anything about it, I think.

Q. Do you, Mr. Mitchell, say cn your oath, that yeu did not on or about, or soon after the location of the Capitol was made, or that you do not know of Crookham's procuring an interest in some property on the east side of the river,-I don't mean the title, but a right to procure a title in certain contingencies ?

[Objected to by counsel for accused, but objection not sustained. The witness declined to answer the question and for reason says:

"It will open my whole private business. I am willing to answer any question relating to the locating of the Capitol."']

The Committee refused to entertain the excuse proffered by the witness, as it does not conform or attempt to conform to the provisions of the statute exempting witnesses from testifying in certain cases.

The counsel for the memorialists decline to question the witness further till the question last put shall be answered.

Mr. McCrary, one of the Committee, thinks the question should be changed so as to enquire of the witness whether he knows of Crookham's owning any property got by the location of the Capitol?

$$
\text { CROSS EXAMINATION. }
$$

Q. Do you know of Mr. Crookham's having received any compensation in money or property, as a consideration or inducement, to locate the Capitol as it was located by the Commissioners ?
A. I do not. 


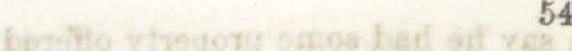

J. B. Stewart, re-called:

Q. State if either of the Commissioners owned any part of the addition in which you spoke of Wells as being interested in ?

A. Yes, I believe I made a conveyance of some lots to the extent of five acres, That interest he purchased of $\mathrm{Van}$ Buskirk at about $\$ 400$-or from $\$ 300$ to $\$ 500$ per acre. The purchase was made by Goodrell in the summer ov tall of 1856 .

Q. Did you see the money paid? telts shim cods ose W is?

A. I did not. The interest had been owned by Baldwin, of Fairfield, and by him sold to $V$ an Buskirk. The deed was made to me by Baldwin. The reason why I know it was purehased by Van Buskirk was that he got the deed and gave it to me, and I gave him, I think, a bond tor two and a half acres. There was a bond given by Van Buskirk to Goodrell for five acres. I lifted that bond and gave Goodrell a bond agreeing to convey lots to him when the tract was divided.

Q. What was the date of the bond from Van Buskirk to Goodrell ?

A. I think it was in the summer of 1856 .

Q. Is this Baldwin of Fairfield a brother of the one who testified here the other night ?

A. I have heard so.

Q. Do you know who Baldwin bought the land of ?

A. He bought it of me.

Q. What time did he pay for it ?

A. Sometime in 1854 or 1855 ; in the winter or spring.

Q. Was it after the law passed for the re-location?

A. It was in the spring of 1855 . He paid me $\$ 35,00$ per acre for it.

Q. Had Van Buskirk any other property on this side of the river?

A. I don't know of any except in the three hundred and sixtytwo acre tract lying north-east of the Capitol square, in Stewart's Addition.

Q. What intetest had Van Buskirk in that tract?

A. I know of his having 14 acres at one time. He bonght and sold a great deal in it.

Q. What interest had he at the time of the location of the Capitol?

A. I think five acres-den't know.
Q. Do you know of Street having any interest here since the location of the Capitol ?

A. No sir. EXPLANATION BY STEWART.

When he, Miller, on your first examination, asked if I expected Wells to use his influence to remove the Capitol. I will réply further that he, Wells, never made any proposition to use his influence, and that I never required it or spoke of it as a condition, and that $I$ never spoke of it at all as connected with that transaction-that all our conversation on the subject of the removal of the Capitol at that time and before, was his conviction that the Capitol would evidently come here, at this town or near it. W

Q. Do you know of the Commissioners receiving anything either directly or indirectly for loeating thenCapitol on the east side of the river ?

A. I do not.

Adjourned.

[Signed]

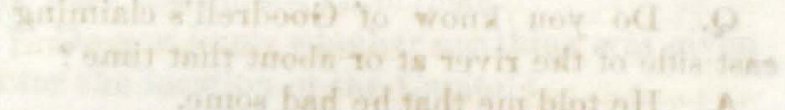
2. A. S. SIBLEY, Clerk.

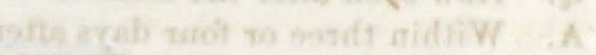

MARCH 6 th, 1858 , Seven o'clock, P. M.

The Committee met pursuant to adjournment.

The parties appeared by their comsel.

J. C. Warner, being duly sworn, testitied as follows:-

Q. Did you have any conversation, with either of the Commissioners at or about the time of the location of the Capitol, and if yea state whom you conversed with and what he said in reference to the location of the Capitol?

A. I had conversation with them-with $\mathbf{M r}$. Goodrell, Crookham and Pegram - at the time of the location, prior and after.

Q. Did either of the Commissioners say to yon anything about making a speculation out of the location?

A. I don t know that they said that. I think one of them said in a jovial way that he intended to make something. This was Mr. Goodrell.

Q. What did Street say?

A. I don't think he said anything about that. We talked several times about the location. I don't think be said anything in 
particular about any particular location. I think Street and two or three others of the Commissioners said they had examined several sites and had found two that would be good sites for the Capitol.

CROSg EXAMINATION.

Q. Were you not in the habit of joking with Mr. Goodreil ?

A. Yes, sir.

Q. Did not Mr. Goedrell say at that time that he would locate the Capitol to the best of his judgment?

A. I don't think he did say so at that time. 'I think I have heard him say so, preveious to that time.

Q. W as the conversation before or after the location?

A. I think it was the evening it was located.

\section{DIRECT EXAMINATION RESLMED.}

Q. Do you know of Goodrell's claiming any property on the east side of the river at or about that time?

A. He told me that he had some.

Q. How soon after the location did he tell you so?

A. Within three or four days after.

CROSG EXAMINATION RESUMED.

Q. Did not Goodrell leave leave within three or four days after the location?

A. I don't know. He said he was going to buy some property on the east side. I think three or tour days after he said he had some or had bought some. He had told me prior to this three or four days that he intended to purchase some.

Q. Did he not tell you he was coming here to live?

A. I think he did. Yes, he told me that.

Q. Did he not return within a month after the location of the Capitol, and might not this conversation have been after he returned?

A. I think not. I think this was within three or four days after the location of the Capitol. We had several conversations after this in which he told me so.

Q. Where were you when the conversation took place, and who were present?

A. I think we were alone. I think it was in Walntut Street nearly in front of the De Moine House.

Q. Did he not tell you he was going to start a lumber yard?
A. I don't think he did. I think that was after he returned; though he might have told me so then.

Q. Did you subscribe to the secret fund to procure the location upon the west side?

A. No, sir. I know of no secret fund.

Q. Did you subscribe for any purpose whatever?

A. I did not-not any amount. I was in partnership. My partner may have. If so it was to the State, not to a secret fund. j Nothing was put down to my knowledge upon any subscription.I have heard my partner subseribed to the State. I don't think it is true.

Q. Were you the proprietor of the De Moine House at the time of the loeation, and were Mr. Goodrell and other Commissioners your guests ?

A. I was, and they were my guests, all of them.

Q. [By Anthony.] Do you know whether anything was given to the Commissioners for the location of the Capitol ?

A. I do not.

W. A. Scott, being duly sworn, testified as follows:-

Q. Where did you reside at the time of the location of the Capitol?

A. At this place, on the east side of the river.

Q. Did you see the Commissioners at the time they were here

to locate the Capitol?

A. I did.

Q. Did you have any conversation with them in reference to the location and before it was determined ?

A. Yes, sir.

Q. Who owned and laid out those additions which I now point out on the map?

A. I and Dean laid out Scott and Dean's Addition. I was interested in the town of Desmoine and in Scott's Addition. I can't tell who owned them unless I go to my private papers.

Q. On which of these, if either, was the Capitol located?

A. It was partly on Scott's Addition to the town of Demoine and partly on Lyon's addition.

Q. Did you, at or about the time of the location of the said 
Capitol, sell and convey, or agree to convey, or agree to hold in trust, any part of your said property for $\mathrm{Mr}$. Street, one of the Commissioners ?

[Objected to by counsel for the accused. The witriess refused to answer the question and filed the following reasen for stuch refnsal :-

"The witness refinses to answer the question on the ground and for the reason that if any any act done, or transaction had, between $\mathrm{Mr}$. Street and this affiant, would tend to impeach the conduct of $\mathrm{Mr}$. Street, it would and will operate to impeach and disgrace affiant; and he further bases his objection and refusal to answer, that the answer which he would be compelled to give, taken in connection with the evidence already taken and questions that might follow - this answer, will tend to disgrace this affiant," '

The Committee refused to excuse the witness from answering the question for the reason that the reason for such refusal does not conform to the requisition of section 2397 of the Code, which exempts witnesses from answering in certain cases.

Q. Did you convey, or agree to convey, or agree to hold any of your said property in trust, for Guy Wells, on or about the time of the location of the Capitol?

[Objected to by the counsel for accused. The witness refused to answer the question and for ground for such refusal gave in the same statement or excuse, as to the last preceding question.

Whereupon the Committee refused to excuse the witness from answering for the same reason stated to the last preceding question and refusal.]

Q. Did you, at or about the time of the location of the Capitol convey, or agree to convey, or to hold in trust, any of your said property for Mr. Pegram?

[Objected to by counsel for the accused. Whereupon the same refinsal and reasons for refusal were given as to the second above written question; and for the reasons following such refusal, the Committee refused to excuse the witness from testifying.]

Q. Did you, or did you not, at or abont the time of the location of the said Capitol, convey or agree to convey, or to hold in trust any portion of your said property, to said Commissioners or to any or to either of them?

[Objected to by counsel for the accused. The witness refused to answer the question, and for exense for such refusal filed the same reasons as to the third above written question. "The Committee refized to exempt the witness from testifying for the reasons stated to the refusal and reasons therefor, to the third above written question.]

II. S. Busic being dnly sworn, testified as follows:

Q. Did you reside here at the time of the location of the Capitol?

A. I resided in Polk county, near Saylorville.

Q. Do you or do you not know of any money or property being promised to be paid or furnished to influence the location of the Capitol on the east side of the Des Moines River? [Objected to by counsel for accused, on the ground that it em. braces too much; which objection was sustained.]

Q. Do you know of said Commissioners having received the promise of any property at or about the time of the location of the Capitol to influence the location where it now is made?

A. I do not.

Q. Did you or did you not sell property on the east side of the river for one or more of the Commissioners ?

A. I did not to my knowledge.

Q. Did you, or did you not carry, or were you or were you not requested to carry money to one or more of said Commissioners, say Pegram or Street; and if you were so requested so to carry, did you or did you not pay the same to the said Pegram or Street? [Objected to as to that part which calls for declarations other than those of Pegram and Street, which was sustained by the Committee.]

A. I never carried any money to either Pegram or Street. I saw none. I handled none.

Q. Do you or do you not know of any or either of the Commissioners claiming any property on the east side of the river, at or about or soon after the location of the Capitol?

A. I heard one of the Commissioners speak of property which I understood from him he owned here. It was sometime after the location. Of my own knowledge I know nothing of it.

oROSS EXAMINATION.

Q. Who was the Commissioner, and how long atter the location, and has he not since been a resident of this town? 
A. It was Mr. Goodrell. I have understood him to be a citizen of this town. It was after he left here after the location and had come back. Sirce then I have understood him to be a citizen here.

The Committee then adjourned.

$$
\text { [Signed] }
$$

\section{S. SIBLEY, Clerk.}

MAROH 8 th, 1858

The Committee met pursuant to call.

Miller appeared for the memorialists and Hall for the accused. The counsel for the accused called M. D. McHenry to the witness stand, who testified as follows:

Q. Were you in the city of Des Moines at the time the Capital was located in $1 \div 56$; if so what time in the day the location was made did you learn the location was made?

A. I came to Des Moines on Monday the 21st of April, 1856, before sunrise of that day. My business here was with $\mathrm{Mr}$. Street, one of the Commissioners. I found him about nine o'clock that morning, and during that forenoon learned from him that although no formal vote of the Commissioners had been taken on the subject he was in favor of the location on the East side himself, and knew enough of the sentiments of others to be satisfied it would be so located. He said they would determine the matter formally that evening, or the next morning as he supposed. Mr. Street introduced me to the other Commissioners and I roomed with them, and may be said to have been one of their company while I remained. On Monday afternoon or Tuesday forenoon - I feel pretty confident it was the latter-I was for the first time introduced to William H. MeHenry, my present partner in business, while he was in the act of fixing the exact position of a section corner, or centre, near the school house, close to the north-west corner of the Capitol Square. He was then defining the exact limits of the square under the direction of the Commissioners, as I was informed on the ground among them, and the fact that they had made the location was spoken of in the crowd as a thing then made known by themselves. I am not certain that I heard any of them say so just then, but it was so stated either by them or by others in their presence, as a matter which they had determined on and made known.
[The latter part of the answer was objected to by the counsel for the memorialists.]

CROSS EXAMTNATION.

Q. Do you reside on the East side of the Des Moines river, and are you interested in property on that side?

A. I live in Des Moines, east side of the river, and own a good many lots on that side-none on the west; and further saith not.

[Signed.] M. D. McHENRY.

H. H. Griffith, being sworn on the part of the accused, testified as follows:

Q. Were you in the eity of Des Moines at the time the Capitol was located in 1856 , if so state what time in the day the location was made did you learn the location was made?

A. I was a resident here at the time-can't say the day exact-

$1 y-m y$ understanding was that it was on Monday evening.

Q. What time in the following day did they commence to survey off the Capitol Square?

A. I can't say-my impression is they commenced the following day.

Q. Do you own property on the East side of the river?

A. Yes, sir.

Q. [By MeCrary.] Do you remember when the survey was made-whether before or after the location?

A. I don't recollect. The day Street came to my house, on Monday evening, sick, my understanding from him was that the location was made. He gave that as a reason why he wanted to leave, and wanted a place to rest.

Q. Did you at or about the time of the location, convey or agree to convey, hold in trust or agree to hold in trust, any property for either ot said Commissioners, or for any person in their behalf, or for them?

[Objected to by counsel for accused and sustained.]

Q. Did you convey or agree to convey any property to influence the location of the Capitol?

[The witness refused to answer this question on the ground that it concerned his own private affairs, which he is under no obliga- 
tion to divulge. Objected to by connsel for accused as not proper cross examination, and as an imposition on any attempt on the part of the respondents to take testimony. The Committee refused to

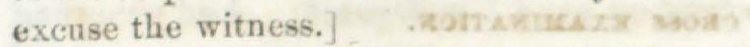

Q. Did you, lat or abont tho time of the loeation of the Capitol, convey or agree to convey, or hold in trust, any property for the Commissioners, or any oir èt hèr of them, or to anybody else/on their behalt, to influence the location of the Capitol?

Ebjected to by counsel as not cross examination, and a palpable violation of every rule of taking testimony.]

A. I answer that question emphatically no. I answer so because I may be liable to misconstruction by refusing to answer, and not because I think the question a proper one.

The Committee then adjourned.

[Signed.]

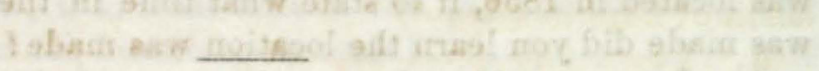

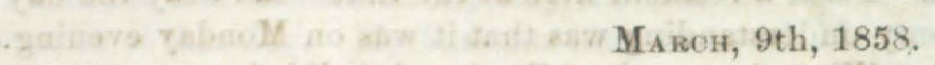

The Committee met pursuant to adjournment.

The parties appeared by their respective cotinsel.

The following witnesses were sworn by the excused:

B. F. Allen, being duly sworn, testified as follows :

Q. Were you a resident in Fort Des Moines at the time the Capitol was located here, in the year 1856 ?

A. 1 was.

Q. Look at this paper [marked "E.?] and state whether you signed that paper, what the circumstances were under which you signed, and whether bona fide on not, and whether it was not got up after there was a report that the Capitol had been located?

A. I did sign it, though I had forgotten it. I did not wish to sign it, but $I$ see it is my name and I now recollect about it. The understanding was, it was told me, that it was got up merely for "bunkum," or sham, and not bona fide, on my part, and it was not oxpected by me that it wonld be paid. I don't recollect; it is so long since I can't tell whether the Capitcl was located at the time or not. I caunct tell for certain; my impression is that it was located.

Q. [By Mahoney.] Do you speak for others as well as yourselt? A. I do not speak tor others. It was a very dear bargain as it was $-\overline{1}$ mean the citizens building a State House and furnishing it free. I thought it enough without giving any $\$ 200,000$ beside.

Q. Look at this subseription paper [marked "F," and answer if the subscribers were responsible at the time : jaspa sa both

A. I suppose they conld all bave paid their subscriptions at that time, as proposed, in property, at the current prices then, though it would have taken abont all some had.

Q. Is not that suluscription extravagant, and would it not have 3 been runous to soine of the parties to have, paid their subscriptions?

A. It would on soune. I have heard some say that it would have been ruinous, or would have almost brokenlsonc, if they had had to pay it at fair prices.

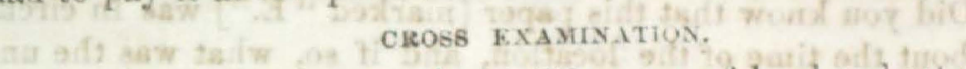

Q. Do you not own about 400 acres of land a short distance north of Capitol Square?

A. I own 180 acres adjoining the corporation, about threefourths of a mile from Capitol Square.

Q. Did you not assert the other day to several persons that you had not signed a subscription?

A. I did. As I said, I had forgotten it. At the time of the location I had much more property on the west side than on the east side of the river, and I still have. A. Did you sign that subscription in good faith, or for the pur pose of working a frand nyon the Com gisgione 's and wpon the

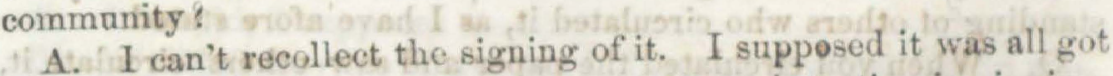
up for "bunkum." I can't say what was my intention in signing. I have forgotten what was my intention. My impression was and still is, that it was all got up for "bunkum."

Q. Since you cannot recollect of signing that paper, and ean't recollect what your intention was in signing it - a matter in which you have and had such a personal interest-how then can you recollect that it is your impression that the subscription was got up for "bunkum?"

A. I can recollect of hearing it talked of at the time as for "bunkum." I know that I had refused to sign it several times, and supposed I had not.

Q. Point out what man or men were not able to pay, upon that subscription. 
A. Barlow Granger for one I do not think was able to pay his subscription of $\$ 2,000$. J. C. Jones, tor another, for $\$ 6,000$.

Q. Was not Granger an agent for Bird of Missouri, and has he not acted as agent in selling and deeding property?

A. He was, but not as late as that I think.

W. W. Williamson, being duly sworn, testified as follows:

Q. Were you a resident of Fort Des Moines at the time of the location of the Capitol ?

A. I was.

Q. Did you know that this paper [marked "E."] was in circulation about the time of the location, and if so, what was the understanding of those who subscribed and circulated it about its being bona fide, and their being required to paytheir subscriptions?

A. I saw the subscription after it was circulated somewhat, and my understanding was, at the time that I subseribed, that the Commissioners had agreed upon a location. I had this only from reports that I heard upon the streets, I think on Tuesday morning, and my recollection now is that at the time $\mathrm{I}$ subscribed that $\mathrm{I}$ did so under the belief that it would not be accepted, for the reason that I had heard that the Commissioners had located the Capitol on the east side. I think I circulated the subscription partly myself. My understanding was such, and I would not give the understanding of others who circulated it, as I have afore stated.

Q. When you circulated the paper and saw others circulate it, how was it represented to others in order to procure subscriptions?

A. I don't recollect of but one instance of any representations being made. There may have been representations in more than one particular case. Mr. Sypher and myself were together and presented the paper to Mr. Holcomb, and he renarked that he had already subscribed something to the State and did not wish to give anything more, and I recollect the reply was made to him that he need not hesitate to sign it for the reason that there was not much danger of his having to give it, or something to that effect. Sypher or myself, I think Sypher, made the reply.

Q. Was Sypher engaged in circulating the paper and getting subscribers?

A. My impression is that he was. It has been so long since 1 cannot say that he circulated the paper only when he was with me.

Q. Look at the paper and see what the aggregate of yours, Sypher's and Holcomb's subseription is ?

A. $\$ 20,500$.

Q. Was not that an extravagant subscription for the persons who subscribed, to make, taking into consideration their ability to pay at that time and since ?

A. It was rather more than a great many of them could pay

3 now. At the time the subscription was made, quite a number, at the price property was then, could pay. Upon looking over the subscription, I don't see any but that might have paid taking property at the price it was at that time.

$$
\text { CROSS EXAMINATION. }
$$

Q. Did yot sign that paper in good faith and with the intent to pay in case the Capitol had been located on the west side of the river?

A. A. Had the location been made on the west side of the river after the subscription had been presented to the Commissioners, I presume I would have paid it.

Q. [By Mahoney.] Did you own property on the west side of the river at that time?

A. Yes.

Q. [By Mahoney.] Would it have been affected by the location on the west side?

A. It would, I suppose.

Q. [By Mahoney.] Were you influenced by that tact in subscribing?

A. In part, I was. I resided on the west side; for convenience to the Capitol I wished to have it there.

Q. To what extent had the subscription been circulated when

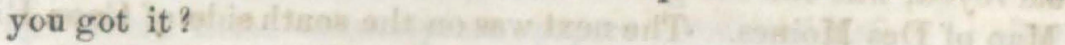

A. I took the subseription to Holcomb. I see that is the seventh name.

Q. How many names did you get to it ?

A. I have no recollection.

Q. Can you name a single subscriber you got beside Holcomb? If so, name him.

A. Francis Grimmel, Jr., I got. I see that is the fourth from the last. I now recollect I went to hunt up Grimmel. I see his 


\section{B6}

name is signed in my land writing. I think I got the subscription of George Sneer. I recolleet no other names I got. I have no doubt I presented it to others.

Q. Do you wish to convey the idea that you got the names from the seventh from the first to the fourth from the last, on the subscription?

A. No, sir; I say no such thing.

V. H. McHenry, being duly sworn, testified as follows:

Q. Did you reside in Des Moines at the time of the location of the Capitol in 1856, and were you called upon to survey the ground upon which the Capitol is located, and other public grounds! if yea, state what time you were called upon, what time you made the survey, and what time you first heard the Capitol was located.

A. I did live here. I was called upon to survey the Capitol grounds. I can't be quite positive about the time. I think, on Monday the 21.st of April, I was called mpon to survey the Capitol grounds. From several circumstances I think it was on Monday the 21at. I am not quite sure whether I commenced the survey the day I was called upon or not. I did make the survey and I commeneed either Monday atternoon or Tuesday forenoon, to the best of my recollection. I can't say exactly when I first heard of the location, but I heard it before I was called upon to make the survey.

Q. What grounds did you first survey, and how long did you continue in the employ of the Commissioners in making surveys?

A. The first survey was on Capitol Square. The next piece I surveyed, was one designated as "State Grounds, " on Bausman's Map of Des Moines. The next was on the south side of Coon Rivex. I was employed three or four days in all.

Q. Do you recollect making any appointment with Judge Crookham to meet him at Campbell's building to make a survey on the south side of Coon River?

A. I Did you do any surveying for Judge Crookham on his private account, or in any other way except as on the public grounds?

A. I never did.

Q. State if you did not have to make an extra survey of tho six-acre lot, east of the Capitol, on account of an objection by Grookham, respecting the quantity of land first surreyed.

A. I think the square was enlarged, and we had to survey a part of it a second time.

Q. How long have you been a resident of Des Moines, and what has been your oceupation and opportunity of knowing the amount of real property held by persons on that subscription ?

A. I have lived in Polk county nine years on the 13th day of f last August. I have been engaged in various kinds of business, and have been operating as surveyor, more or less, all of the time, in the county. I have been Sheriff of this county. By association and surveying land for parties, I have had an opportunity of form. ing some idea of the amount of property owned by parties.

Q. Looking over the subscription do you not consider the amounts subscribed by some parties as extravagant, and beyond their means at the time and since to pay?

A. I think the subseriptions very extravagant for some,-others $\rightarrow$ could pay it.

Benjamin Bryant, being duly sworn, testified as follows:-

Q. How long have you lived in the town of Des Moines ? .

A. I have resided in Polk county since May 6th, 1843.

Q. Were you in Fort Des Moines at the time of the location of the Capitol?

3) A. Yes.

Q. Did you see the subscription paper, marked "E, " abont the time the Capitol was located?

A. I don't know that I ever saw this thing as it is. I saw a subseription similar to this in character.

Q. Were these snbscription papers circulated before or after reports said the Capitol was located?

A. Before and on the day the Capitol was located. After I knew the Capitol was located, subscriptions were around and I was asked to subscribe to them.

Q. Were these subseriptions circulated considered as "binkum," or bona fide?

A. Those circulated before the location I considered as boma ficle, and tor the purpose of getting the Capitol on the west side of 
river. Those after the location, I understood were for the purpose of showing that there could be a certain amount of money raised on the west side of the river.

Q. Were not the subscriptions raised betere the location to be given to influence the Commissioners to locate the Capitol on the west side of the river ?

A. The first one I don't know about. I think it was to see what smount could be raised. It was to be put into the hands of a Committee. Think it was spoken of, as to see what amount could be raised to build temporary buildings for the State.

Q. Look at the subscription paper, marked "E," and state if the subscriptions of many are not extravagant and beyond the ability of the subscribers at that time and since to pay?

A. Several I can mention, I think the subscriptions of, would be extravagant, - others would not.

The Committee then adjourned.

[Signed.]

\section{S. SIBLEY, Clerk.}

MARCH 10th, 1858.

The Committee met pursuant to call by the Chairman. The following witnesses were ealled by the Committee:

C. J. L. Foster, being duly sworn, testified as follows:

Q. State whether you had any conversation with Mr. Crookham concerning the location of the Capitol, and if so what that conversation was ?

A. Mr. Crookham came into my room at the Grout House, one evening since his arrival here, some tine last week. I commenced talking with him in a jovial, joking sort of a way, about the location of the Capitol. He went on to say that the location was about the best that could be made. He said he got here on Sunday night, when he came to locate the Capitol, and found the people here in a great contest about the location. The people on the west side came over and presented a subscription of a large amount, if they would locate the Capitol over there on the west side. On Monday he said they went over on the west side and looked around and examined the location offered. He, Crookham, took a bond for ten acres of land, I think he said for the location of the Capitol, or State University upon. He said the proposition from the west side was received in the forenoon of Monday, and they went over to examine the west side in the afternoon. On Tuesday, he said, we looked on the east side. The subscription from the west side they received on Monday, and made the location on Tuesday.This he repeated upon my question. He said he rode around on the east side, and on returning said to the other Commissioners that he had made a location, and it was upon the hill, where it now is, and the other Commissioners said they agreed with him as to f the location. He, Crookham, was Secretary of the Board of Commissioners, and they passed a resolution on Tuesday afternoon to locate the Capitol on its present site. He said he had all the proceedings of the Board at his office. I asked why he did not bring them up. He said he did not consider it of enough consequence, or something to that effect. $\mathrm{He}$, Crookham, thought it was the best location that could be made, and it was none of their business how many lots they got. He, Crøokham, seemed quite indignant that they should have called up this investigation.

$>$

Joseph Grimes, being duly sworn, testified as follows:

Q. [By the Chairman.] State whether you heard any conversation by $\mathrm{Mr}$. Crookham about the location of the Capitol, and if so, what he, Crookham, said.

A. I heard Crookham speaking about the location at the Grout House, some time from the first to the fifth instant, one evening. $\mathrm{He}$, Crookham, said he came here to locate the Capitol on Sunday

3 night. The Commissioners had a proposition trom the other side. They, the Commissioners, went on the other side to look on Monday. My impression is that he said the bond he got there was for ten acres on the other side of the forks on the hill, and was for some of the Institutions. He said they received the propositions, which was a subscription of a considerable amount and I don't remember what, - from the west side on Monday, and they went over and looked at the location offered after they received the proposition. The day after they went over on the west side, he said they located the Capitol here on the east side. He said that at night after the location was made some of them from the west side came over to see about it, late at night; but they told them it was too late. He, Crookham, went on to say that it was none of their business how much they got or how much money they received. This 
conversation was voluntary on the part of $\mathrm{Mr}$. Crookham. He commenced talking about it, and directed his conversation mainly to. Mr. Foster. This occurred last week, sometime about the first part or middle of the week.

The Committee then adjonrned.
[ Signed]
S. SIBLEY, Clerk.

\section{COPY OF THE SUBSCRIPTIONS ON THE WEST SIDE} OF THE RIVER.

We, the undersigned, severally promise and agree to donate to the State of Iowa, Real Estate, to be appraised by disinterested persons, to the value of the several sums ret against our respective names, Provided, The Commissioners appointed for the re-location of the State Capitol, locate the same in the forks of the Des Moines and Raccoon Rivers.

Fort Des Moines, Iowa, April 22d, 1856.

P. M. Casady, ....... $\$ 5,000 \quad$ R. W. Sypher, ..... $\$ 10,000$

S. Y. Keene, ........5,000 Jonathan Lyon, .......15,000

L. P. Sherman, ........300 James Campbell, . . . .5,000

W. H. Hervey, . . . . . . L 1,000 Lovell White, ........3,000

Ira Cook, .........4,000 F. R. West, .......10,000

F. C. Grimmel, ......10,000 Wm. F. Ayres, ...... 5,000

R. Holcomb, ........10,000

E. R. Clapp,$\ldots \ldots \ldots \ldots \ldots 00$

J. D. Davis, .......... 1,000

J. Lewis, ..........1,000

H. Stephenson, .........300

H. R. Lovejoy, ........ 300

L: T. Filson, .........1,000

William Busick, .......500

B. F. Allen, ........2, 2,000

J. W. Bradshaw, ...... 1,000 Edwin Hall, ........2,000

And. J. Stevens, . . . . . 2,000

G. Holland, . . . . . . . 5,000

W. C. Burton, ....... 3,000

Francis Grimmel, Jr., . . 1,000

George Sneer,.........1,000

Thos. MeMullen,......5,000

J. C. Jones, . . . . . . . 6, 6,000

J. S. Dicks, ...........500

W. W. Moore, .........500

H. M. Hoxie, . . . . . . 1,000

Hoyt Sherman, . . . . . . 3,000

J. E. Jewett, . . . . . . . 2,000

B. Rice,............500

D. P. W. Day, . . . . 2, 2,000

R. L. Tidrick, . . . . . 1,000

H. C. Grimmel, . . . . . . 400

D. O. Finch, ......... 500

W. W. Williamson, .....500

James Crane, ..........500

James Sherman,.......500

$\$ 71,900$

$\$ 56,900$

71,900

$\$ 128,800$ 
[B.]

COPY OF NOTICE SERVED UPON THE COMMISSIONERS BY PEOPLE OF WEST SIDE.

Fr. Des Mornes, April 22, 1856.

To the Boàd of Commissioners, appointed by his Honor, J. W. Grimes, for the re-location of the Seat of Government of the State of Iowa:

You are hereby notified that the citizens of the town of Ft. Dea Moines will on to-morrow morning offer, through you, to the State of Iowa, ten acres of land, in an eligible situation and in a suitable place, and within the territory fixed by law for said location, and two hundred thousand dollars if said location shall be made on the West side of the Des Moines river and within the Raccoon forks. J. E. JEWETT.
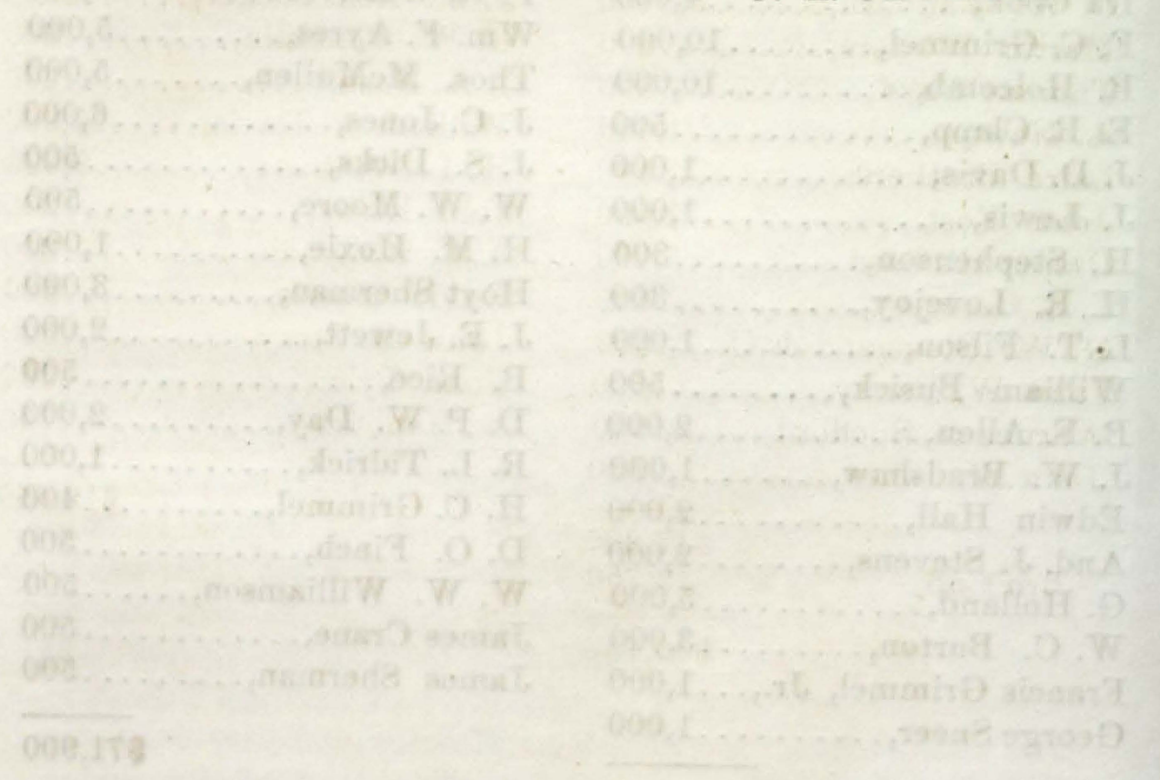

\section{[C.]}

COPY OF THE SECOND SUBSCRIPTION PAPER.

We the undersigned severally promise and agree to donate to the State of Iowa, Real Estate, to be appraised by disinterested persons to the amount of the several sums set against our respective names, Provided, the Commissioners to re-locate the State Capitol, do locate the same in the forks of the Des Moines and Raccoon rivers:

John Mumma,........\$500

Barlow Granger, for Bird, 2,000

Wesley Redhead, ........1,000

Milton Scett, .........1,000

C.H. \& W. A. Poindexter, 5,000

Wm. M. Baker, . . . . 1, 1,000

C. W. Vanhorn, .......400

Martin Winters,........600

Thomss Boyd, ..........300

A. Newton, .......... 1,000

Laird Brothers, .........500

John Yost,...........1,000

Casper Hibbard, . . . . . . 1,000

J. S. Cook, ........... 500

G. W. Cleveland \& Co.,..500

John W. Penny, ........500

Warner \& Spofford,.....500
Leas \& Harsh, ........\$500

Thompson Bird,.......5,000

H. R. Lovejoy, .......200

B. Bryant, .......... 500

James Stanton, ........200

F. Palmer, ......... 500

J. M. Reichsucker, ......200

R. W. Concklin, ......200

J. A. Nash, ............500

William P. Davis, .....1,000

H. L. Whitman, . . . . 2, 2000

John Kirby,...........200

A. S. Kingman, .......200

David Norris,.........500

John H. Story, ........ 500

John Tyler,............300

A. Hepburn, . . . . .......150

$\overline{\$ 12,650}$ 
[D.]

S'TATEMENT OF TWO COMMISSIONERS TO THE COMMITTEE OF INVESTIGATION.

The undersigned, late Commissioners to re-locate the Capitol of the State of Iowa, being charged with the other Commissioners with fraud, corruption and bribery in their acts in fixing the location as now fixed by law, beg leave to present to the Committee of Investigation the following statement:

That at the fime the location was made all of the Commissioners. were present, and made the examination that they deemed necessa$r y$ in order to come to a correct opinion in regard to the proper place to locate the Capitol. They waited upon eitizens and examined different donations proposed to be made. That after consultation the Commissioners were unanimously of opinion that the location made was for the best interest of the State. It is unnecessary to state all the reasons and causes that were taken into consideration in forming their judgment.

After the Commissioners had acted and decided, the citizens, or some of them, residing on the West side of the river, made some propositions that had not been previously made, and which were not considered by the Commissioners.

The undersigned deny that they or either of them, or any other of the Commissioners, to their knowledge, acted under the inflnence of any gift or bribe made by any person whatsoever, but on the contrary they decided upon the question presented to them aecording to their honest convictions and best judgment.

The undersigned deny in the most emphatic manner each and all of the allegations and charges so nnjustly presented by the memorialists.

[Signed.]

GUY WELLS, STEWART GOODRELL.

\section{[E]}

COPY OF THE FIRST SUBSCRIPTION PAPER.

We the undersigned severally promise and agree to donate to the State of Iowa, Real Estate, to be appraised by disinterested persons, to the valne of the several sums set against our respective names, Provided, The Commissioners appointed for the re-location of the State Capitol, locate the same in the forks of the Des Moines and Raccoon Rivers.

Fort Des Moines, Iowa, April 22d, 1856.

P. M. Casady, ........ $\$ 5,000$

S. Y. Keene, ......... 5,000

L. P. Sherman, ........300

Wm. H. Hervey, . . . . . 1,000

Ira Cook, ............4,000

F. C. Grimmel, .......10,000

R. Holcomb, . . . . . 10,000

E. R. Clapp, ............500

J. D. Davis, ........... 1,000

J. Lewis, ............1,000

H. Stephenson, ..........300

H. R. Lovejoy, . . . . . . . . 300

I. T. Filson, .........1,000

William Busick, .........500

B. F. Allen, .........2, 2,000

J. W. Bradshaw, ...... 1,000

Edwin Hall, . . . . . . . . 2,000

R. W. Sypher, .......10,000

Jonathan Lyon, ........15,000

James Dampbell, . . . . . 5,000

Lovell White, ......... 3,000

F. R. West, ......... 10,000

$$
\begin{array}{r}
\$ 87,900 \\
40,900
\end{array}
$$

$\$ 128,800$
Wm. F. Ayers, ......... ..5,000

Thos. MeMullen, . . . . . .5,000

J. C. Jones, . . . . . . . 6,000

J. S. Dicks, .......... 500

W. W. Moore, ..........500

H. M. Hoxie, ........ 1,000

Hoyt Sherman,.........3,000

J. E. Jewett, . . . . . . . . 2,000

B. Rice, ................500

D. P. W. Day, ....... . 2,000

R. L. Tidriek, ......... 1,000

H. C. Grimmel, . . . . . . . 400

And. J. Stevens, . . . . ...2,000

G. Holland, . ........ 5,000

D. O. Finch, ...........500

W. W. Williamson, .......500

W. C. Burton, . ........ 3,000

Francis Grimmel, Jr.,...1,000

George Sneer,.........1,000

James Crane, ..........500

James Sherman, ........500

$\$ 40,900$ 
[F.]

SPECIFIC CHARGES.

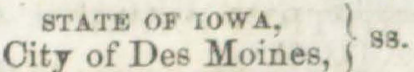

Before Committee of the House of Representatives appointed to investigate charges of fraud on the part of the Commissioner's in locating the Capitol:

The memorialists in this case offer to prove and expect to prove:

That the several Commissioners appointed pursuant to the provisions of an act of the General Assembly of the State of Iowa, approved January 25th, 1855, entitled "An Act to re-locate the Seat of Government," in making the location of the Seat of Government did not perform said duty with a strict regard to the interests of the entire State:" but did proceed to locate and establish the said Seat of Government at the point where the inhabitants and proprietors of the land did offer to and did pay said Commissioners the largest personal bribe or bonus for locating the same.

That notwithst nding the people and citizens residing on the west side of the Wes Moines river and within the limits provided in the said act for the location of the same, offered to donate to the State sufficient lands for public use, and to make the State a donation of lands to the amount of two hundred thousand dollars or thereabout besides, to have the Seat of Government located on that side of the river, the Commissioners did locate the same on the east side of the river without any donation of lands to the State, other than for public buildings, (or without any donation amounting to any considerable sum,) and did receive in consideration of said location sums in land and money amounting to from seven to ten thousand dollars to each of said Commissioners-all of which took place and occurred in the spring of 1856 .

That while the question of making said location, to wit in the apring of 1856 , was before said Commissioners and pending, they or a majority of them suffered themselves to be and were improperly inflaenced in their decision, and were induced to make and did make their said location for the promotion of private and personal ends, and not with a "gtrict regard to the interests of the entire State," as required by law ; and being. so influenced and improperly induced, the said location was made by them against the true interests of the State, and without regard to the same.

[Signed.]
W. C. BURTON THOS. MoMULLIN, A. N. MARSH, J. S. COOK, JAMES CRANE JAS. SHERMAN, H. M. BUSH, H. K. LOVEJOY, F. C. GRIMMEL.

\section{[G.]}

REASONS OF THE MEMORIALISTS FOR URGING A FULL INVESTIGATION.

In the matter of the memorial for an investigation of frauds and undue influence in the location of the State Capitol under the Act of 1855 :

It is held by the Memorialists as follows:

They appear as citizens of the State, and claim that the investigation should be had because

First-It is due to the dignity of the State, which, if their charges are true, has been grievously outraged.

Second-If there was no other purpose, the Legislature has the right to the information to enable them better to guard against such frauds in future legislation.

Third-The State has the right, and is impelled by duty, to ferret out all wrongs and frauds committed by her agents against her dignity and her interests in order to evince alike her condemnation of such condnct, and her determination that no such action will be permitted to remain hidden and nndiscovered.

Fourth-But further than this, the act of the 25th of January, 1855, charged these Commissioners with certain duties, among which was that of locating the Capitol within a certain district for the best interests of the State, in the language of the act, thus :"that in making said re-location they will have strict regard to the interests of the entire State." [ [8 8.]

"It shall be their duty in making said re-location, to obtain at least as much land as is necessary for the Capitol buildings, and may be practicable to obtain without charge to the State, and also any and all grants and donations of land and town-lots within their power to the State."

It is therefore a right and a duty of the Legislature to inquire, upon intormation given them, whether these functions have been honestly performed by the Commissioners.

Fifth-Especially is it a right and duty to ascertain whether they did so obtain all grants and donations in their power to the State; because if they obtained them for themselves, instead of the State, they would be chargeable in a Court of Equity, as trustees of the State, with every foot of land given to them individually, in consideration of their official action, and could be compelled to account to the State therefor, or for its proceeds in ease of sale. 
Sixth-They have a further right to ascertain the question of fraud in the re-location, in order that, if the State is dissatisfied with the ten acres selected, and prefers another lot for the permanent Capitol, they r $\mathrm{may}$ feel at entire liberty to do so withont feeling any apprehension of inequity towards the persons who so donated this land to the State; and also, by ascertaining what offers were made then to the Commissioners of much larger grants of land, to the far greater benefit of the State, to judge on the one hand of the bad faith of the Commissioners, and the other of the propriety of yet accepting those offers, if still open to the State.

Seventh-In addition to the foregoing the Memorialists contend that the Constitution does not provide for the site of a building, but for a municipal district containing the Seat of Government, and that anywhere within this municipal district the site of the Capitol, the building is within the power of the Legislature: and that neither Governor, nor prior Legislature, nor Convention, nor the people, can by any possibility be considered as having ratified the fraud, if any. Fraud, and undiscovered fraud especially, is never ratitied by any department of government, though it may be overlooked.
MEMORIAL FOR THE INVESTIGATION.

To the Honorable, the Speaker of the House of Representatives

of the Legislature of the State of Iorod:

Your Memorialists, eitizens of Polk county in said State, would respectfully represent, that they have good and sufficient reason to believe, that in the location of the Capitol at Des Moines under the Act entitled An Act "to re-locate the Seat of Government," the Commissioners appointed for the purpose of selecting a suitable location, did not in accordance with the provisions of the said act, and their oaths of oftice, faithfully and impartially discharge their several duties, and further that we are fully satisfied that in the present location the aforesaid Commissioners did not act for the best interests of the State as prescribed in said act.

Your Memorialists would further represent that we believe and are satisfied that we can show fraud and corruption on the part of the Commissioners and others sufficient to canse this Legislature to set aside the acts of the Commissioners. We would therefore respectfully urge upon your honorable body the importance of appoiuting a Committee, fully empowered to send for persons and papers, and enter into a full and impartial investigation of all matters pertaining to the re-location of the Capitol.
J. S. Cook,
C. C. Howell,
John S. Smith,

John L. Smith,

J. C. Lovejoy,

Wm. Baker,

J. F. Kemp,

John T'yler,

D. P. W. Day,

D. P. Kenyon,

W. C. Burtou,

H. M. Bush,

J. D. Davis,

A. Newman,

A. N. Marsh,

J. A. Woods,

Samuel Gruell,

Wm. MoClelland, Jr. Wm. Phillips,

Chas. Wietz,

Joseph Rogg,

John Johns,

James Crane,

F. W. Chaffee,

H. R. Lovejoy,

Greenup Scott,

$\mathrm{Wm}$. Allen,

James Sherman,

J. S. Dicks,

C. P. Luce,

L. T. Filson,

G. W. Dunkle,

D. Harris,

J. A McConahay, John H. Given,

F. C. Grimmel, Jr., D. D. Skinner,

Jacob Lehman,
H. C. Grimmel,

C. Lehman,

E. R. Sanford,

David Norris,

P. M. Seott,

W. W. Moore,

George Green,

R. W. Concklin,

R. W. Sypher,

S. MeCain,

John H. Thode,

E. R. Clapp,

R. Holcombe,

I. J. Harrod,

H. Stephenson,

Francis C. Grimmei,

Johnathan Lyon.
C. W. Vanhorn, 